\title{
De arbeidsmarkt voor informatici
}

Citation for published version (APA):

Smits, W., Delmee, J., \& de Grip, A. (1998). De arbeidsmarkt voor informatici. Researchcentrum voor Onderwijs en Arbeidsmarkt, Faculteit der Economische Wetenschappen. ROA Reports No. 2 https://doi.org/10.26481/umarep.1998002

Document status and date:

Published: 01/01/1998

DOI:

10.26481/umarep.1998002

Document Version:

Publisher's PDF, also known as Version of record

\section{Please check the document version of this publication:}

- A submitted manuscript is the version of the article upon submission and before peer-review. There can be important differences between the submitted version and the official published version of record.

People interested in the research are advised to contact the author for the final version of the publication, or visit the DOI to the publisher's website.

- The final author version and the galley proof are versions of the publication after peer review.

- The final published version features the final layout of the paper including the volume, issue and page numbers.

Link to publication

\footnotetext{
General rights rights.

- You may freely distribute the URL identifying the publication in the public portal. please follow below link for the End User Agreement:

www.umlib.nl/taverne-license

Take down policy

If you believe that this document breaches copyright please contact us at:

repository@maastrichtuniversity.nl

providing details and we will investigate your claim.
}

Copyright and moral rights for the publications made accessible in the public portal are retained by the authors and/or other copyright owners and it is a condition of accessing publications that users recognise and abide by the legal requirements associated with these

- Users may download and print one copy of any publication from the public portal for the purpose of private study or research.

- You may not further distribute the material or use it for any profit-making activity or commercial gain

If the publication is distributed under the terms of Article $25 \mathrm{fa}$ of the Dutch Copyright Act, indicated by the "Taverne" license above, 


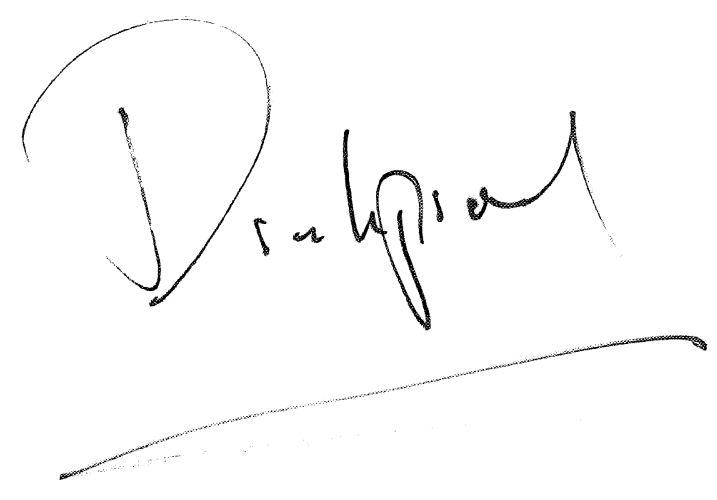

De arbeidsmarkt voor informatici

ROA-R-1998/2

W. Smits

J. Delmee

A. de Grip

Researchcentrum voor Onderwijs en Arbeidsmarkt

Faculteit der Economische wetenschappen en Bedrijfskunde Universiteit Maastricht

Maastricht, januari 1998 
Tweede druk

ISBN 90-5321-218-3

SEC97123.wp7/WS 


\section{Inhoud}

Bladzijde

Voorwoord $i$

1 Inleiding 1

2 De werkgelegenheid in informatica-beroepen 5

2.1 Inleiding 5

2.2 Informatica-beroepen 5

2.3 Werkgelegenheidsontwikkelingen in het informatica-domein 9

2.4 De werkgelegenheid naar bedrijfssector $\quad 11$

3 De arbeidsmarktpositie van informatici: Recente ontwikkelingen en actuele situatie

3.1 Inleiding 17

3.2 Werkgelegenheidsontwikkelingen $\quad 17$

3.3 Recent afgestudeerden van informatica-opleidingen 20

$\begin{array}{ll}3.4 \text { Beloning van informatici } & 24\end{array}$

4 Opleidingsachtergrond van werkenden in het informatica-domein 27

$\begin{array}{ll}4.1 \text { Inleiding } & 27\end{array}$

4.2 Substitutiemogelijkheden tussen opleidingen 27

4.3 Aansluiting tussen opleiding en beroep in het informatica-domein $\quad 30$

5 Toekomstige ontwikkelingen op de arbeidsmarkt voor informatici, 1997-2002 37

$\begin{array}{ll}5.1 \text { Inleiding } & 37\end{array}$

5.2 Verwachte werkgelegenheidsontwikkelingen en knelpunten bij $\begin{array}{ll}\text { informatica-beroepen } & 39\end{array}$

5.3 Verwachte knelpunten bij informatica-opleidingen 41

6 Internationale vergelijking $\quad 49$

6.1 Inleiding 49

6.2 De arbeidsmarkt voor informatici in Duitsland 49

6.3 De arbeidsmarkt voor informatici in Groot-Brittannië 53

7 Conclusies $\quad 55$

$\begin{array}{ll}\text { Literatuur } & 59\end{array}$

Bijlage 1 Informatica-beroependomein 61

Bijlage 2 Indicator voor knelpunten in de personeelsvoorziening per beroep $\quad 65$ 



\section{Voorwoord}

Er zijn diverse signalen die wijzen op een tekort aan informatici. Een structureel tekort aan informatici kan op den duur nadelige gevolgen hebben voor de Nederlandse economie. Het is daarom van belang om een goed inzicht te krijgen in de ernst van de tekorten. Om deze reden heeft de Adviesraad voor Wetenschaps en Technologiebeleid (AWT) het Researchcentrum voor Onderwijs en Arbeidsmarkt (ROA) onderzoek laten doen naar de arbeidsmarkt voor informatici. Dit rapport is het resultaat van dit onderzoek.

De auteurs danken Marien van der Velden van Intermediair online voor het beschikbaar stellen van enkele analyses op basis van de Intermediair loopbaanenquête. 


\section{Inleiding}

De werkgelegenheid op het gebied van de informatica is in de laatste decennia sterk toegenomen. De grootste groei deed zich voor eind jaren '80. Deze werkgelegenheidstoename is een direct gevolg van de toegenomen automatiseringsgraad van bedrijven. In 1997 zal bij naar verwachting $80 \%$ van de bedrijven in de particuliere sector sprake zijn van administratieve automatisering (CBS, 1997b). Ook de industriële automatisering heeft de laatste jaren een flinke vlucht genomen. Volgens het CBS werd in 1995, bijvoorbeeld, door $30 \%$ van de bedrijven gebruik gemaakt van computer systemen voor productontwikkeling (Computer Aided Design) terwijl dat in 1984 nog slechts bij 6\% van de bedrijven het geval was (CBS,1997a). De penetratiegraad van andere vormen van industriële automatisering zoals automatisering ter ondersteuning van de planning (Computer Aided Planning) en automatisering ter ondersteuning van het productieproces (Computer Aided Manufacturing) ligt zelfs nog wat hoger. Parallel aan deze ontwikkelingen loopt een forse groei van het aantal dienstverlenende bedrijven in de automatiseringsbranche. Tussen 1987 en 1995 groeide de werkgelegenheid in deze branche van ruim 28.000 naar ongeveer 62.000 personen (CBS, 1997a).

Begin jaren negentig is de werkgelegenheid in informatica-beroepen overigens enigszins gestabiliseerd. Voor de komende jaren wordt echter weer een verdere groei van de werkgelegenheid verwacht. Naast de verder voortschrijdende informatisering is ook de 'jaar 2000 problematiek' verantwoordelijk voor de verwachte groei van de werkgelegenheid in de informatica. Het gaat hier om een extra vraag naar informatici als gevolg van de problemen die zich zullen voordoen bij het omschakelen van computersystemen naar het jaar 2000.

Er zijn reeds enige tijd diverse signalen die wijzen op een tekort aan informatici. Verschillende werkgevers in de automatiseringsbranche betalen 'aanbrengpremies' voor het binnenbrengen van nieuw personeel (NRC handelsblad, 11 juni 1997). Verder blijkt bijvoorbeeld uit de KIvl vacature-barometer dat de vacatures voor ingenieurs in de computerservice- en informatietechnologie in het eerste kwartaal van 1997 fors zijn gestegen (Nibbering en Nitzsche, 1997). Ook uit andere bronnen blijkt dat er sprake is van een groei van de vacatures voor automatiseringspersoneel. Zo blijkt uit vacaturecijfers van Intermediair dat het vacature-aanbod voor mensen met een informaticaopleiding op WO-niveau in het derde kwartaal van 1997 met $57 \%$ is gestegen ten opzichte van het vacature-aanbod in het derde kwartaal van 1996 (Bron: Intermediair Arbeidsmarktanalyse). Ten slotte meldt Berenschot op grond van een salarisenquête onder bedrijven dat het aantal vacatures als percentage van de totale werkgelegenheid voor automatiseerders $9,8 \%$ bedraagt. Het aantal vacatures voor personen met een informatica-opleiding op HBO- of WO-niveau blijkt zelfs nog wat hoger te liggen, namelijk op 13,7\%. Overigens heeft het grootste deel van de vacatures betrekking op HBO'ers, ongeachtof ze een opleiding in de informatica hebben gevolgd. 
Een probleem van vacaturecijfers als indicator voor tekorten aan bepaalde groepen arbeidskrachten is echter de mogelijkheid dat werkgevers reeds rekening houden met bestaande tekorten en daarom bij voorbaat hun eisen al bijstellen. Stel, bijvoorbeeld, dat een vacature het best kan worden opgevuld door iemand met een informaticaopleiding op HBO-niveau. Met enige bijscholing is het echter ook mogelijk om iemand met een HBO-opleiding in een andere richting de vacature te laten opvullen. Als werkgevers anticiperen op tekorten aan mensen met de gewenste opleiding HBO informatica zullen ze de opleidingseisen verruimen, of zelfs op een geheel ander arbeidsmarktsegment mensen proberen aan te trekken (bijvoorbeeld afgestudeerden uit de alpha- of gamma-richtingen). Het resultaat is dan dat het aantal vacatures voor afgestudeerden uit alpha- en gamma-richtingen binnen het $\mathrm{HBO}$ toeneemt, terwijl de werkelijke knelpunten zich voordoen bij de opleiding HBO informatica.

Dit probleem zal zich met name voordoen in relatief nieuwe beroepsterreinen, zoals de automatiseerdersbranche. Toen deze branche begon op te komen waren er nauwelijks dagopleidingen die speciaal op automatiseringberoepen gericht waren. Daardoor kwamen mensen met een uiteenlopende initiële opleidingsachtergrond die vaak aanvullende automatiseringscursussen hadden gevolgd of gingen volgen in deze functies terecht. In dit verband is het ook interessant op te merken dat het aantal cursisten dat een automatiseringscursus volgde bij het particulier onderwijs met name in de jaren tachtig erg hoog was. Met het toegenomen aanbod van dagopleidingen is de belangstelling voor cursussen echter afgenomen en het aantal cursisten is in 1995 in vergelijking met 1990 meer dan gehalveerd (CBS 1997a). Deze ontwikkelingen lijken er op te wijzen dat in de toekomst het aandeel van mensen die een reguliere opleiding in de informatica hebben afgerond zal toenemen.

De mogelijke tekorten aan met name hoog opgeleide informatici kunnen op den duur nadelige gevolgen hebben voor de concurrentiepositie van de Nederlandse economie. Het is daarom van belang om goed inzicht te krijgen in de ernst en omvang van deze tekorten. Vanuit deze achtergrond zal in dit rapport de arbeidsmarkt voor informatici in Nederland worden belicht. Er zal zowel een beeld worden gegeven van de arbeidsmarktontwikkelingen gedurende de afgelopen jaren als van de verwachte toekomstige ontwikkelingen.

De arbeidsmarkt voor informatici zal vanuit twee invalshoeken worden belicht. Ten eerste zal worden gekeken naar de ontwikkelingen in de informatica-beroepen. Op basis van de door het CBS gehanteerde werksoorten per beroep (CBS, 1993) zal worden bekeken welke beroepen tot het informatica-domein kunnen worden gerekend. Vervolgens zal worden onderzocht welke beroepen in het informatica-domein het meeste last zullen hebben van tekorten aan mensen met een opleiding in de informatica. Zoals eerder werd opgemerkt heeft een groot deel van de werkenden in de informatica-beroepen (oorspronkelijk) geen informatica-opleidingsachtergrond. Tekorten zijn in het verleden veelal opgelost door mensen met een andere opleidingsachtergrond 
te rekruteren. Nagegaan zal worden wat de belangrijkste opleidingsachtergronden zijn van werkenden binnen de informatica-beroepen.

Ten tweede zal worden ingegaan op de ontwikkelingen per opleidingtype. Daarbij zullen de opleidingstypes $M B O / L L W$ automatisering, HBO informatica en WO informatica en bestuurlijke informatiekunde worden onderscheiden. Hoewel de interesse primair uitgaat naar de arbeidsmarktsituatie voor hoger opgeleiden, worden waar mogelijk ook middelbaar opgeleiden in de analyses betrokken vanwege de mogelijke substitutieprocessen tussen de verschillende opleidingsniveaus. Er zal een beeld worden gegeven van recente ontwikkelingen in de arbeidsmarktpositie van personen met een informatica-opleiding. Verder zal per opleidingstype de verwachte toekomstige vraag met het toekomstige aanbod worden geconfronteerd om inzicht te krijgen in de verwachte tekorten per opleidingstype en de oorzaken van deze tekorten.

Daarnaast zal worden onderzocht welke problemen de instroom van personen zonder een informatica-opleiding in de informatica-beroepen met zich mee kan brengen. Daarbij zal worden nagegaan of schoolverlaters die werkzaam zijn in een informaticaberoep maar geen informatica-opleidingsachtergrond hebben vaker aansluitingsproblemen ondervinden dan schoolverlaters die wel een informatica-opleidingsachtergrond hebben. Interessant daarbij is de vraag of deze aansluitingsproblemen er ook toe leiden dat personen zonder een informatica-opleidingsachtergrond vaker IT-cursussen volgen. Als er inderdaad sprake is van grotere aansluitingsproblemen zal dit ook gevolgen kunnen hebben voor de beloning. Vanuit dit oogpunt zal ook de beloning in informaticaberoepen worden geanalyseerd.

Bij het onderzoek is gebruik gemaakt van verschillende databronnen. Gegevens over vraag- en aanbodontwikkelingen zijn afkomstig uit het ROA Informatiesysteem Onderwijs-Arbeidsmarkt (zie ROA, 1997a,b) en de Enquête Beroepsbevolking van het CBS. Informatie over schoolverlaters met een informatica-opleidingsachtergrond en schoolverlaters die werkzaam zijn in een informatica-beroep is afkomstig uit de schoolverlatersenquêtes RUBS, HBO-Monitor en WO-monitor.

Het rapport is verder als volgt opgebouwd. In hoofdstuk 2 wordt een beeld gegeven van de recente ontwikkelingen in de werkgelegenheid in de informatica-beroepen. Daarna wordt in hoofdstuk 3 ingegaan op de recente ontwikkelingen en de actuele situatie op de arbeidsmarkt voor informatici. In hoofstuk 4 wordt gekeken naar verschillen tussen personen met een informatica-opleidingsachtergrond en personen met een opleiding in een andere richting die werkzaam zijn in informatica-beroepen. Vervolgens worden in hoofstuk 5 de verwachte toekomstige arbeidsmarktontwikkelingen besproken. Hoofstuk 6 vergelijkt de situatie in Nederland met de situatie in Duitsland en GrootBrittannië. Ten slotte worden in hoofdstuk 7 de belangrijkste resultaten van het rapport samengevat en enkele conclusies getrokken. 


\section{De arbeidsmarkt voor informatici}

ROA-R-1998/2

W. Smits

J. Delmee

A. de Grip

Researchcentrum voor Onderwijs en Arbeidsmarkt

Faculteit der Economische wetenschappen en Bedrijfskunde

Universiteit Maastricht

Maastricht, januari 1998 


\section{Inhoud}

Bladzijde

Voorwoord

1 Inleiding 1

2 De werkgelegenheid in informatica-beroepen 5

2.1 Inleiding 5

2.2 Informatica-beroepen 5

2.3 Werkgelegenheidsontwikkelingen in het informatica-domein 9

2.4 De werkgelegenheid naar bedrijfssector 11

3 De arbeidsmarktpositie van informatici: Recente ontwikkelingen en actuele $\begin{array}{ll}\text { situatie } & 17\end{array}$

$\begin{array}{ll}3.1 \text { Inleiding } & 17\end{array}$

$\begin{array}{ll}3.2 \text { Werkgelegenheidsontwikkelingen } & 17\end{array}$

$\begin{array}{ll}3.3 \text { Recent afgestudeerden van informatica-opleidingen } & 20\end{array}$

$\begin{array}{ll}3.4 \text { Beloning van informatici } & 24\end{array}$

4 Opleidingsachtergrond van werkenden in het informatica-domein 27

$\begin{array}{ll}4.1 \text { Inleiding } & 27\end{array}$

4.2 Substitutiemogelijkheden tussen opleidingen 27

4.3 Aansluiting tussen opleiding en beroep in het informatica-domein $\quad 30$

5 Toekomstige ontwikkelingen op de arbeidsmarkt voor informatici, 1997-2002 37

$\begin{array}{ll}5.1 \text { Inleiding } & 37\end{array}$

5.2 Verwachte werkgelegenheidsontwikkelingen en knelpunten bij $\begin{array}{ll}\text { informatica-beroepen } & 39\end{array}$

5.3 Verwachte knelpunten bij informatica-opleidingen 41

6 Internationale vergelijking 49

6.1 Inleiding 49

6.2 De arbeidsmarkt voor informatici in Duitsland 49

6.3 De arbeidsmarkt voor informatici in Groot-Brittannië 53

7 Conclusies $\quad 55$

$\begin{array}{ll}\text { Literatuur } & 59\end{array}$

$\begin{array}{ll}\text { Bijlage } 1 \text { Informatica-beroependomein } & 61\end{array}$

Bijlage 2 Indicator voor knelpunten in de personeelsvoorziening per beroep $\quad 65$ 


\section{Voorwoord}

Er zijn diverse signalen die wijzen op een tekort aan informatici. Een structureel tekort aan informatici kan op den duur nadelige gevolgen hebben voor de Nederlandse economie. Het is daarom van belang om een goed inzicht te krijgen in de ernst van de tekorten. Om deze reden heeft de Adviesraad voor Wetenschaps en Technologiebeleid (AWT) het Researchcentrum voor Onderwijs en Arbeidsmarkt (ROA) onderzoek laten doen naar de arbeidsmarkt voor informatici. Dit rapport is het resultaat van dit onderzoek.

De auteurs danken Marien van der Velden van Intermediair online voor het beschikbaar stellen van enkele analyses op basis van de Intermediair loopbaanenquête. 


\section{Inleiding}

De werkgelegenheid op het gebied van de informatica is in de laatste decennia sterk toegenomen. De grootste groei deed zich voor eind jaren ' 80 . Deze werkgelegenheidstoename is een direct gevolg van de toegenomen automatiseringsgraad van bedrijven. In 1997 zal bij naar verwachting $80 \%$ van de bedrijven in de particuliere sector sprake zijn van administratieve automatisering (CBS, 1997b). Ook de industriële automatisering heeft de laatste jaren een flinke vlucht genomen. Volgens het CBS werd in 1995, bijvoorbeeld, door $30 \%$ van de bedrijven gebruik gemaakt van computer systemen voor productontwikkeling (Computer Aided Design) terwijl dat in 1984 nog slechts bij $6 \%$ van de bedrijven het geval was (CBS,1997a). De penetratiegraad van andere vormen van industriële automatisering zoals automatisering ter ondersteuning van de planning (Computer Aided Planning) en automatisering ter ondersteuning van het productieproces (Computer Aided Manufacturing) ligt zelfs nog wat hoger. Parallel aan deze ontwikkelingen loopt een forse groei van het aantal dienstverlenende bedrijven in de automatiseringsbranche. Tussen 1987 en 1995 groeide de werkgelegenheid in deze branche van ruim 28.000 naar ongeveer 62.000 personen (CBS, 1997a).

Begin jaren negentig is de werkgelegenheid in informatica-beroepen overigens enigszins gestabiliseerd. Voor de komende jaren wordt echter weer een verdere groei van de werkgelegenheid verwacht. Naast de verder voortschrijdende informatisering is ook de 'jaar 2000 problematiek' verantwoordelijk voor de verwachte groei van de werkgelegenheid in de informatica. Het gaat hier om een extra vraag naar informatici als gevolg van de problemen die zich zullen voordoen bij het omschakelen van computersystemen naar het jaar 2000.

Er zijn reeds enige tijd diverse signalen die wijzen op een tekort aan informatici. Verschillende werkgevers in de automatiseringsbranche betalen 'aanbrengpremies' voor het binnenbrengen van nieuw personeel (NRC handelsblad, 11 juni 1997). Verder blijkt bijvoorbeeld uit de KIvI vacature-barometer dat de vacatures voor ingenieurs in de computerservice- en informatietechnologie in het eerste kwartaal van 1997 fors zijn gestegen (Nibbering en Nitzsche, 1997). Ook uit andere bronnen blijkt dat er sprake is van een groei van de vacatures voor automatiseringspersoneel. Zo blijkt uit vacaturecijfers van Intermediair dat het vacature-aanbod voor mensen met een informaticaopleiding op WO-niveau in het derde kwartaal van 1997 met $57 \%$ is gestegen ten opzichte van het vacature-aanbod in het derde kwartaal van 1996 (Bron: Intermediair Arbeidsmarktanalyse). Ten slotte meldt Berenschot op grond van een salarisenquête onder bedrijven dat het aantal vacatures als percentage van de totale werkgelegenheid voor automatiseerders $9,8 \%$ bedraagt. Het aantal vacatures voor personen met een informatica-opleiding op HBO- of WO-niveau blijkt zelfs nog wat hoger te liggen, namelijk op $13,7 \%$. Overigens heeft het grootste deel van de vacatures betrekking op HBO'ers, ongeachtof ze een opleiding in de informatica hebben gevolgd. 
te rekruteren. Nagegaan zal worden wat de belangrijkste opleidingsachtergronden zijn van werkenden binnen de informatica-beroepen.

Ten tweede zal worden ingegaan op de ontwikkelingen per opleidingtype. Daarbij zullen de opleidingstypes MBO/LLW automatisering, HBO informatica en WO informatica en bestuurlijke informatiekunde worden onderscheiden. Hoewel de interesse primair uitgaat naar de arbeidsmarktsituatie voor hoger opgeleiden, worden waar mogelijk ook middelbaar opgeleiden in de analyses betrokken vanwege de mogelijke substitutieprocessen tussen de verschillende opleidingsniveaus. $\mathrm{Er}$ zal een beeld worden gegeven van recente ontwikkelingen in de arbeidsmarktpositie van personen met een informatica-opleiding. Verder zal per opleidingstype de verwachte toekomstige vraag met het toekomstige aanbod worden geconfronteerd om inzicht te krijgen in de verwachte tekorten per opleidingstype en de oorzaken van deze tekorten.

Daarnaast zal worden onderzocht welke problemen de instroom van personen zonder een informatica-opleiding in de informatica-beroepen met zich mee kan brengen. Daarbij zal worden nagegaan of schoolverlaters die werkzaam zijn in een informaticaberoep maar geen informatica-opleidingsachtergrond hebben vaker aansluitingsproblemen ondervinden dan schoolverlaters die wel een informatica-opleidingsachtergrond hebben. Interessant daarbij is de vraag of deze aansluitingsproblemen er ook toe leiden dat personen zonder een informatica-opleidingsachtergrond vaker IT-cursussen volgen. Als er inderdaad sprake is van grotere aansluitingsproblemen zal dit ook gevolgen kunnen hebben voor de beloning. Vanuit dit oogpunt zal ook de beloning in informaticaberoepen worden geanalyseerd.

Bij het onderzoek is gebruik gemaakt van verschillende databronnen. Gegevens over vraag- en aanbodontwikkelingen zijn afkomstig uit het ROA Informatiesysteem Onderwijs-Arbeidsmarkt (zie ROA, 1997a,b) en de Enquête Beroepsbevolking van het CBS. Informatie over schoolverlaters met een informatica-opleidingsachtergrond en schoolverlaters die werkzaam zijn in een informatica-beroep is afkomstig uit de schoolverlatersenquêtes RUBS, HBO-Monitor en WO-monitor.

Het rapport is verder als volgt opgebouwd. In hoofdstuk 2 wordt een beeld gegeven van de recente ontwikkelingen in de werkgelegenheid in de informatica-beroepen. Daarna wordt in hoofdstuk 3 ingegaan op de recente ontwikkelingen en de actuele situatie op de arbeidsmarkt voor informatici. In hoofstuk 4 wordt gekeken naar verschillen tussen personen met een informatica-opleidingsachtergrond en personen met een opleiding in een andere richting die werkzaam zijn in informatica-beroepen. Vervolgens worden in hoofstuk 5 de verwachte toekomstige arbeidsmarktontwikkelingen besproken. Hoofstuk 6 vergelijkt de situatie in Nederland met de situatie in Duitsland en GrootBrittannië. Ten slotte worden in hoofdstuk 7 de belangrijkste resultaten van het rapport samengevat en enkele conclusies getrokken. 


\section{De werkgelegenheid in informatica-beroepen}

\subsection{Inleiding}

In dit hoofdstuk zal worden ingegaan op de werkgelegenheidsontwikkeling in de informatica-beroepen. Allereerst zal in paragraaf 2.2 bekeken worden welke beroepen tot het informatica-domein gerekend kunnen worden. Ook wordt nagegaan welke

- vaardigheden in dit domein vereist zijn. Daarna gaat paragraaf 2.3 in op de recente ontwikkelingen in de werkgelegenheid in informatica-beroepen en op de kenmerken van de werkenden in dit beroependomein. Tenslotte wordt in paragraaf 2.4 aandacht geschonken aan het belang van de informatica-functies voor verschillende bedrijfssectoren.

\subsection{Informatica-beroepen}

Voordat we in kunnen gaan op de werkgelegenheidsontwikkelingen in de informaticaberoepen moeten eerst de criteria worden vastgesteld op basis waarvan een beroep kan worden getypeerd als een informatica-beroep. Een methode voor het typeren van beroepen is om een analyse te maken van de werkzaamheden die in een beroep worden uitgevoerd. Het CBS heeft de beroepen die worden onderscheiden in de Standaard Beroepenclassificatie 1992 (SBC'92) getypeerd aan de hand van werksoorten (CBS, 1993). Er zijn twee werksoorten die betrekking hebben op informatica namelijk informatica ontwikkelen, adviseren (werksoort 20) en informatica beheren, verwerken (werksoort 21). Op basis van deze werksoorten zullen hier de informatica-beroepen worden getypeerd. Alle beroepen waarvoor tenminste één van deze werksoorten van belang is rekenen we tot de informatica-beroepen. Appendix 1 geeft een overzicht van deze informatica-beroepen. Voor onze analyses zullen we echter steeds uitgaan van beroepsgroepen. Binnen een beroepsgroep worden meerdere beroepen samengenomen. Het kan voorkomen dat onder een bepaalde beroepsgroep zowel informatica-beroepen als andere beroepen vallen. Een beroepsgroep rekenen we tot het informatica-domein als het aandeel van informatica-beroepen binnen deze beroepsgroep voldoende groot is. Het aandeel van een beroep binnen een beroepsgroep wordt bepaald op basis van het aantal werkenden in een beroep (zie ook Borghans e.a., 1997)

Tabel 2.1 geeft per beroepsgroep het percentage werkenden dat de werksoort informatica ontwikkelen, adviseren uitvoert. Het blijkt dat informatica ontwikkeling en/of advisering met name in beroepen op HBO- en wetenschappelijk niveau voorkomt. In de beroepsgroep Informatici voeren alle werkenden deze werksoort uit. Bij de beroepsgroepen Technische systeemanalisten en Systeemanalisten is dat $80 \%$ van de werkenden. Ten slotte blijkt ook een aanzienlijk deel van de werkenden in de beroepsgroep Elektrotechnici dergelijke werzaamheden te verrichten. 
Tabel 2.1

Percentage werkenden per beroepsgroep dat informatica ontwikkelt en/of erover adviseert, 1994

\begin{tabular}{lr} 
Beroepsgroep & $\%$ \\
\hline Technisch systeemanalisten & 79 \\
Systeemanalisten & 83 \\
Elektrotechnici & 41 \\
Informatici & 100 \\
Totaal (alle werkenden) & 1 \\
\hline Bron: ROA/CBS &
\end{tabular}

Bron: ROA/CBS

Tabel 2.2 geeft dezelfde cijfers voor de werksoort Informatica beheren, verwerken. Deze werksoort wordt met name in de beroepen op middelbaar niveau uitgevoerd. Alle werkenden in beroepen die tot de beroepsgroep Programmeurs worden gerekend houden zich bezig met beheren en/of verwerken van informatica. Bij de Systeemanalisten is dat slechts bij $21 \%$ het geval, terwijl bij de Elektronicamonteurs slechts $2 \%$ dergelijke werkzaamheden uitvoert. Overigens is de beroepsgroep Systeemanalisten de enige beroepsgroep waar beide informatica-werksoorten voorkomen.

Tabel 2.2

Percentage werkenden per beroepsgroep dat informatica beheert en verwerkt, 1994

\begin{tabular}{lr} 
Beroepsgroep & $\%$ \\
\hline Elektronicamonteurs & 2 \\
Programmeurs & 100 \\
Systeemanalisten & 21 \\
Totaal (alle werkenden) & 1 \\
\hline Bron: ROA/CBS
\end{tabular}

Bron: ROA/CBS

Ten slotte geeft tabel 2.3 een overzicht van het percentage werkenden per beroepsgroep dat minstens één van beide informatica-werksoorten uitvoert. Ongeveer $2 \%$ van de totale beroepsbevolking verricht werkzaamheden op het terrein van de informatica. Bij de beroepsgroep Elektronicamonteurs is het percentage dat zich met informatica bezig houdt zo laag dat we deze beroepsgroep niet tot het informatica-domein zullen rekenen. In de beroepsgroep Elektrotechnici verricht ongeveer $40 \%$ van de werkenden werkzaamheden op het gebied van de informatica. Hoewel ook dit percentage duidelijk lager is dan bij de andere beroepsgroepen waar informaticawerkzaamheden voorkomen is het aandeel toch nog zo aanzienlijk dat deze beroepsgroep tot het informaticadomein gerekend zal worden.

Het informatica-beroependomein omvat derhalve de volgende beroepsgroepen Programmeurs, Technische systeemanalisten, Systeemanalisten, Electrotechnici en Informatici. De beroepsgroep Programmeurs omvat alle automatiseerdersberoepen op 
middelbaar niveau, met de nadruk op administratieve toepassingen. De beroepsgroep Technisch systeemanalisten omvat alle informatica-beroepen op hoger niveau, waarbij de nadruk ligt op technische toepassingen. De beroepsgroep systeemanalisten heeft daarentegen betrekking op de hogere informatica-beroepen, die gericht zijn op administratieve toepassingen. De informatica-beroepen die vallen onder de beroepsgroepen Electrotechnici en Informatici hebben allen een wetenschappelijk niveau. Bij de beroepsgroep Electrotechnici ligt de nadruk op technische toepassingen en bij informatici op administratieve toepassingen ${ }^{1}$.

Tabel 2.3

Percentage werkenden per beroepsgroep dat werkzaamheden op het gebied van de informatica verricht, 1994

\begin{tabular}{lr}
\hline Beroepsgroep & $\%$ \\
\hline Elektronicamonteurs & 2 \\
Programmeurs & 100 \\
Technisch systeemanalisten & 79 \\
Systeemanalisten & 97 \\
Elektrotechnici & 41 \\
Informatici & 100 \\
Totaal (alle werkenden) & 2 \\
\hline
\end{tabular}

Bron: ROA/CBS

Op basis van de CBS classificatie is het ook mogelijk om enig inzicht te geven in de vaardigheden die in dit informatica-domein vereist zijn $^{2}$. Voor elke onderscheiden vaardigheid is per beroepsgroep in het informatica-domein nagegaan welk percentage van de werkenden werkzaam is in een beroep waarvoor deze vaardigheid vereist is. Het is niet verwonderlijk dat voor alle beroepen die tot het informatica-domein worden gerekend kwantitatieve vaardigheden vereist zijn. Daarnaast is de service-gerichtheid van groot belang in het informatica-domein. Technische vaardigheden zijn vooral van belang voor Elektrotechnici en in iets mindere mate voor Technische systeemanalisten. Leidinggevende kwaliteiten zijn alleen van belang in de beroepsgroep Informatici, hoewel in deze beroepsgroep ook slechts een kwart van de werkenden over deze vaardigheden hoeft te beschikken. Voor de beroepsgroep informatici zijn verder ook persuasieve vaardigheden belangrijk. Ruimtelijk voorstellingsvermogen is alleen van belang voor Elektrotechnici en Technische systeemanalisten. Organisatorische, verbale vaardigheden en oplettendheid zijn zelden van belang in het informatica-domein.

1. In Appendix 1 wordt een koppeling gelegd tussen de beroepsgroepen in het informaticadomein en de beroepen die het Landelijk Dienstverlenend Centrum voor Studie- en beroepskeuzevoorlichting (LDC) onderscheidt in de publicatie Beroepen van $A$ tot $Z$ (LDC, 1996).

2. Alle beroepen in de SBC'92 zijn namelijk getypeerd naar vaardigheden die vereist zijn om het beroep uit te oefenen. Het CBS onderscheid 11 vaardigheden en elk beroep is getypeerd naar maximaal 7 van deze vaardigheden (zie CBS, 1993). 


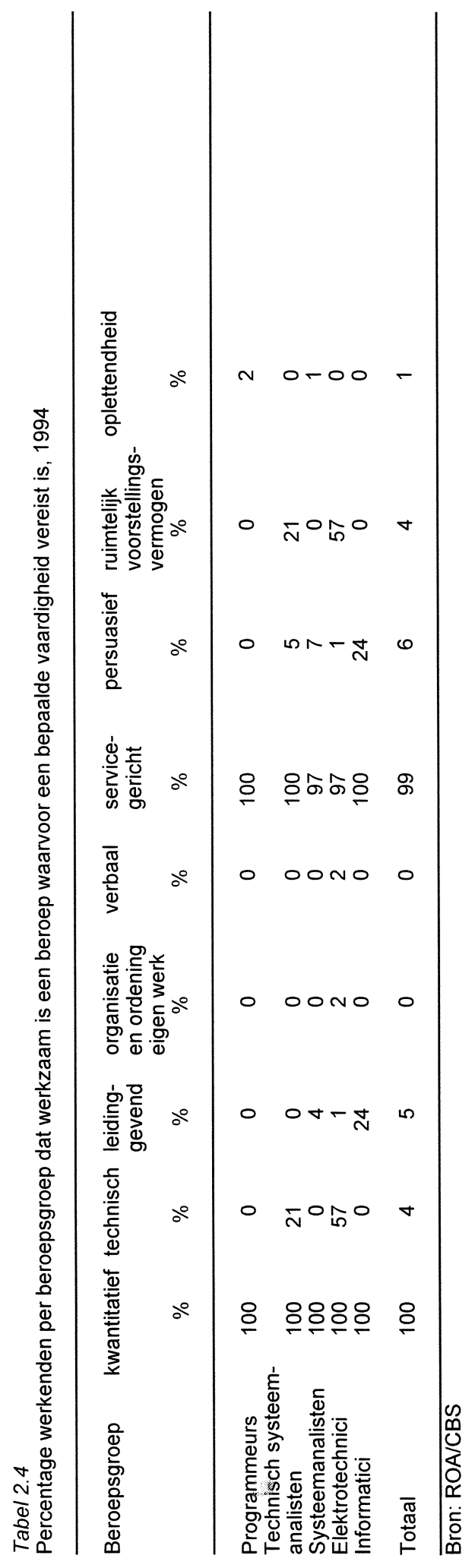




\subsection{Werkgelegenheidsontwikkelingen in het informatica-domein}

In het informatica-domein werken ongeveer 161 duizend personen. De grootste beroepsgroep vormen de Systeemanalisten die bijna 50\% van de totale werkgelegenheid in het informatica-domein uitmaken. Verder is ruim $30 \%$ van de werkenden in het informatica-domein werkzaam in de beroepsgroep Programmeurs. De werkgelegenheid in de beroepsgroepen Technisch systeemanalisten, Elektrotechnici en Informatici is veel geringer, zij maken respectievelijk $6 \%, 4 \%$ en $9 \%$ van de totale werkgelegenheid in het informatica-domein uit.

Tabel 2.5

Aantallen werkenden in het informatica-domein, gemiddelde 1995-1996 en de werkgelegenheidsgroei 1992-1996

\begin{tabular}{lcc}
\hline Beroepsgroep & $\begin{array}{c}\text { aantal werkenden } \\
\text { gemiddelde 1995-1996 }\end{array}$ & $\begin{array}{c}\text { groei 1992-1996 } \\
\%\end{array}$ \\
& & \\
\hline Programmeurs & 51.000 & 28 \\
Technisch systeemanalisten & 10.000 & 6 \\
Systeemanalisten & 78.500 & 17 \\
Elektrotechnici & 7.000 & 6 \\
Informatici & 14.500 & 13 \\
Totaal & 161.000 & 17 \\
\hline
\end{tabular}

Bron: ROA/CBS

De totale werkgelegenheid in het informatica-domein is in de periode 1992-1996 met ongeveer 17\% gestegen. De grootste groei deed zich voor na 1994, zoals figuur 2.1 laat zien. In het begin van de jaren negentig was de werkgelegenheid nog vrij stabiel ${ }^{3}$. Overigens zijn hier duidelijke verschillen tussen de beroepsgroepen zichtbaar. De werkgelegenheid in de beroepsgroep Programmeurs begint reeds vanaf 1993 sterk te stijgen. Deze beroepsgroep laat dan ook de hoogste groei zien over de periode 19921996. Daarentegen daalt de werkgelegenheid in de beroepsgroep Technische systeemanalisten in de periode 1992-1995 om pas in 1996 sterk te gaan groeien. De werkgelegenheid in de beroepsgroep Elektrotechnici is de laatste jaren juist wat afgenomen.

3. De gegevens zijn mogelijk iets vertekend omdat het CBS vanaf 1996 ook het beroep is gaan coderen van mensen met een tijdelijke baan, korter dan een half jaar, zonder vooruitzicht op verlenging. Beroepsgroepen waarin tijdelijke contracten relatief vaak voorkomen geven daardoor een grotere werkgelegenheidsgroei te zien dan in werkelijkheid het geval is. 
Figuur 2.1

Aantal werkenden in het informatica-domein

Informatica-domein

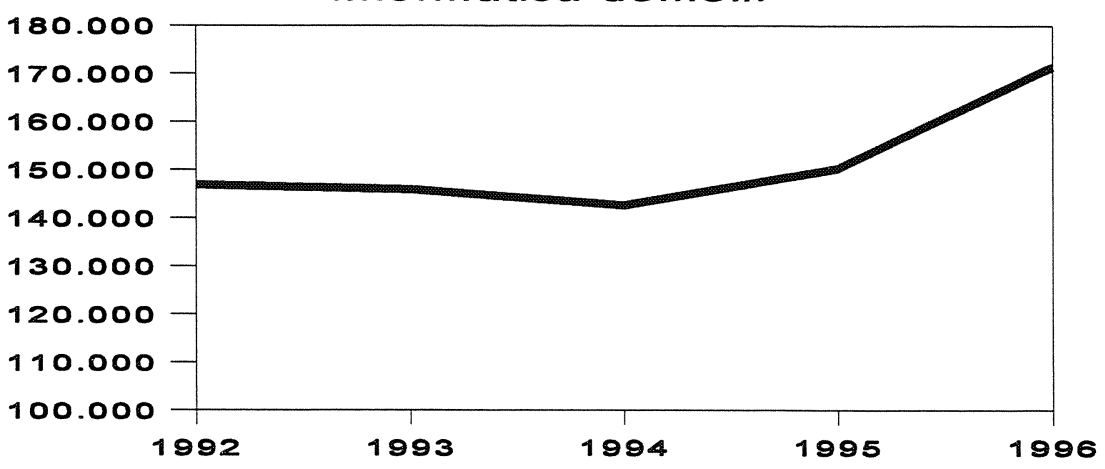

Vrouwen

Tabel 2.6 geeft een overzicht van het percentage vrouwen dat werkzaam is in het informatica-domein. Dit percentage is erg laag voor Elektrotechnici, laag voor Technisch systeemanalisten en gemiddeld voor Programmeurs, Systeemanalisten en Informatici. Bovendien neemt het aandeel van vrouwen in deze beroepsgroepen ook niet toe.

Tabel 2.6

Percentage vrouwen per beroepsgroep in het informatica-domein, gemiddelde 1995-1996

\begin{tabular}{|c|c|c|c|}
\hline Beroepsgroep & $\%$ & typering & $\begin{array}{l}\text { trend } \\
1992-' 96\end{array}$ \\
\hline $\begin{array}{l}\text { Programmeurs } \\
\text { Technisch systeemanalisten } \\
\text { Systeemanalisten } \\
\text { Elektrotechnici } \\
\text { Informatici }\end{array}$ & $\begin{array}{r}13 \\
- \\
12 \\
- \\
-\end{array}$ & $\begin{array}{l}\text { gemiddeld } \\
\text { laag } \\
\text { gemiddeld } \\
\text { erg laag } \\
\text { gemiddeld }\end{array}$ & $\begin{array}{l}\text { sterk dalend } \\
\text { sterk stijgend } \\
\text { constant } \\
- \\
\text { constant }\end{array}$ \\
\hline Totaal (alle werkenden) & 37 & gemiddeld & constant \\
\hline
\end{tabular}

Bron: CBS/ROA

Leeftijdsopbouw

Tabel 2.7 gaat in op de leeftijdsopbouw van werkenden in het informatica-domein. De tabel laat zien dat de leeftijdsopbouw in de meeste beroepsgroepen in het informaticadomein vrij jong is. In de beroepsgroepen Programmeurs en Systeemanalisten is slechts respectievelijk $7 \%$ en $6 \%$ van de werkenden ouder dan 50 jaar, terwijl dat voor de totale beroepsbevolking $15 \%$ is. Dit heeft natuurlijk vooral te maken met het feit dat de werkgelegenheid in deze beroepsgroepen pas de laatste decennia sterk in opkomst is, waardoor relatief veel jongeren zijn aangetrokken. 
Tabel 2.7

Percentage jongeren (15-29 jaar) en ouderen (50-64 jaar) per beroepsgroep in het informaticadomein, gemiddelde 1995-1996

\begin{tabular}{|c|c|c|c|c|}
\hline Beroepsgroep & ${ }_{\%}^{j c}$ & $\begin{array}{l}\text { trend } \\
1992-96\end{array}$ & $\%$ & $\begin{array}{l}\text { trend } \\
\text { 1992-'96 }\end{array}$ \\
\hline $\begin{array}{l}\text { Programmeurs } \\
\text { Technisch systeemanalisten } \\
\text { Systeemanalisten } \\
\text { Elektrotechnici } \\
\text { Informatici }\end{array}$ & $\begin{array}{l}22 \\
31 \\
23 \\
38 \\
23\end{array}$ & $\begin{array}{l}\text { sterk dalend } \\
\text { constant } \\
\text { - } \\
\text { stijgend } \\
\text { stijgend }\end{array}$ & $\begin{array}{l}7 \\
- \\
6 \\
- \\
-\end{array}$ & $\begin{array}{l}\text { sterk stijgend } \\
\text { sterk dalend } \\
\text { sterk stijgend } \\
\text { - } \\
\text { - }\end{array}$ \\
\hline Totaal (alle werkenden) & 29 & dalend & 15 & constant \\
\hline
\end{tabular}

\subsection{De werkgelegenheid naar bedrijfssector}

Er zijn aanzienlijke verschillen in de automatiseringsgraad tussen bedrijfssectoren. In de bouwnijverheid is de automatiseringraad, zowel met betrekking tot de administratieve als de industriële automatisering, bijvoorbeeld vrij laag, terwijl in de metaalindustrie de automatiseringsgraad juist hoog is (zie CBS, 1997a, b). Daarom zal ook het belang van informatica-beroepen verschillen tussen bedrijfssectoren. In deze paragraaf zal in worden gegaan op de werkgelegenheid in het informatica-domein per bedrijfssector.

Tabel 2.8 geeft de index voor bedrijfssectorspreiding per beroepsgroep in het informatica-domein. Naarmate de waarde van deze spreidingsindex hoger is voor een beroepsgroep, is de werkgelegenheid in deze beroepsgroep meer gespreid over de verschillende bedrijfssectoren (zie bijvoorbeeld Borghans, e.a., 1995). De beroepsgroep Programmeurs kent de grootste spreiding over de verschillende bedrijfssectoren. Ook de werkgelegenheid in de beroepsgroepen Technische systeemanalisten, Systeemanalisten en Elektrotechnici is flink gespreid. De werkgelegenheid in de beroepsgroep Informatici is daarentegen wat meer geconcentreerd in enkele bedrijfssectoren. Dat betekent dat bij een tekortschietend aanbod voor deze beroepsgroep, knelpunten vooral bij enkele specifieke bedrijfssectoren zullen optreden. Bij een tekortschietend aanbod voor de overige beroepsgroepen in het informatica-domein zullen daarentegen over de gehele linie knelpunten worden ondervonden.

Tabel 2.9 geeft een beeld van het belang van de beroepsgroepen in het informaticadomein voor de diverse bedrijfssectoren. De tabel geeft per bedrijfssector een indicatie van de trendmatige ontwikkeling en indien mogelijk het werkgelegenheidsaandeel van de informatica-beroepen in de totale werkgelegenheid. De tabel laat zien dat het aandeel van beroepsgroepen die tot het informatica-domein worden gerekend in veel sectoren sterk stijgend is. 
Tabel 2.8

Uitwijkmogelijkheden naar verschillende bedrijfssectoren per beroepsgroep in het informaticadomein, gemiddelde 1995-1996

\begin{tabular}{lcl}
\hline Beroepsgroep & spreidingsindex & typering \\
& & \\
\hline Programmeurs & 13,02 & erg hoog \\
Technisch systeemanalisten & 10,35 & hoog \\
Systeemanalisten & 7,56 & hoog \\
Elektrotechnici & 9,22 & hoog \\
Informatici & 4,47 & gemiddeld \\
\end{tabular}

Bron: ROA/CBS

Tabel 2.9

Het belang van informatica-beroepsgroepen per bedrijfssector: werkgelegenheid als percentage van de totale werkgelegenheid in de bedrijfssector, gemiddelde 1995-1996 en trend

\begin{tabular}{|c|c|c|}
\hline Bedrijfssector & $\%$ & trend 1994-1996 \\
\hline Tuinbouw & - & - \\
\hline Veehouderij & - & - \\
\hline Akkerbouw, bosbouw en visserij & - & - \\
\hline Vlees- en visverwerking & - & - \\
\hline $\begin{array}{l}\text { Overige voedingsproducten } \\
\text { Programmeurs } \\
\text { Systeemanalisten }\end{array}$ & - & $\begin{array}{l}\text { sterk stijgend } \\
\text { sterk stijgend }\end{array}$ \\
\hline $\begin{array}{l}\text { Drank en tabaksproducten } \\
\text { Systeemanalisten }\end{array}$ & - & sterk stijgend \\
\hline $\begin{array}{l}\text { Basischemie } \\
\text { Programmeurs } \\
\text { Informatici }\end{array}$ & - & $\begin{array}{l}\text { sterk dalend } \\
\text { sterk stijgend }\end{array}$ \\
\hline $\begin{array}{l}\text { Eindproducten chemie } \\
\text { Systeemanalisten } \\
\text { Programmeurs }\end{array}$ & - & $\begin{array}{l}\text { constant } \\
\text { sterk stijgend }\end{array}$ \\
\hline $\begin{array}{l}\text { Kunststofverwerking } \\
\text { Programmeurs }\end{array}$ & - & sterk stijgend \\
\hline $\begin{array}{l}\text { Basismetaal } \\
\text { Programmeurs } \\
\text { Systeemanalisten }\end{array}$ & - & $\begin{array}{l}\text { stijgend } \\
\text { sterk stijgend }\end{array}$ \\
\hline $\begin{array}{l}\text { Metaalproducten } \\
\text { Programmeurs } \\
\text { Systeemanalisten }\end{array}$ & - & $\begin{array}{l}\text { sterk stijgend } \\
\text { sterk dalend }\end{array}$ \\
\hline $\begin{array}{l}\text { Machine-industrie } \\
\text { Systeemanalisten } \\
\text { Programmeurs }\end{array}$ & - & $\begin{array}{l}\text { sterk stijgend } \\
\text { sterk stijgend }\end{array}$ \\
\hline
\end{tabular}


Tabel 2.9 (vervolg)

Het belang van informatica-beroepsgroepen per bedrijfssector: werkgelegenheid als percentage van de totale werkgelegenheid in de bedrijfssector, gemiddelde 1995-1996 en trend

Elektrotechniek

Systeemanalisten

Elektrotechnici

Technisch systeemanalisten

Programmeurs

Informatici

Transportmiddelen

Systeemanalisten

Programmeurs

\section{Textiel}

Hout- en bouwmaterialen

Papier

Grafische industrie

Programmeurs

Systeemanalisten

\section{Energie}

Systeemanalisten

Programmeurs

Bouw

Systeemanalisten

Programmeurs

Technisch systeemanalisten

Exploitatie van onroerend goed

\section{Handel}

Systeemanalisten

Programmeurs

Informatici

Technisch systeemanalisten

Elektrotechnici

Scheeps- en luchtvaart

Systeemanalisten

Weg- en railvervoer

Programmeurs

Systeemanalisten

Communicatie

Programmeurs

Systeemanalisten

Elektrotechnici

Technisch systeemanalisten

\section{Bankwezen}

Systeemanalisten

Programmeurs

Informatici

Technisch systeemanalisten constant

dalend

sterk stijgend

sterk stijgend

onbekend

sterk dalend

sterk stijgend

-

sterk stijgend sterk stijgend

dalend

dalend

sterk stijgend

sterk stijgend sterk stijgend

constant

sterk stijgend sterk dalend stijgend

sterk stijgend

sterk dalend

sterk stijgend

sterk dalend

sterk stijgend sterk stijgend sterk stijgend onbekend

stijgend

constant

dalend

sterk stijgend 
Tabel 2.9 (vervolg)

Het belang van informatica-beroepsgroepen per bedrijfssector: werkgelegenheid als percentage van de totale werkgelegenheid in de bedrijfssector, gemiddelde 1995-1996 en trend

\begin{tabular}{|c|c|c|}
\hline Bedrijfssector & $\%$ & trend 1994-1996 \\
\hline \multicolumn{3}{|l|}{ Verzekeringswezen } \\
\hline Systeemanalisten & 5 & sterk stijgend \\
\hline Programmeurs & 3 & dalend \\
\hline Informatici & - & sterk stijgend \\
\hline Horeca & - & - \\
\hline Reparatie & - & - \\
\hline \multicolumn{3}{|l|}{ Zakelijke dienstverlening } \\
\hline Systeemanalisten & 6 & stijgend \\
\hline Programmeurs & 2 & constant \\
\hline Informatici & 1 & stijgend \\
\hline Technisch systeemanalisten & 1 & sterk dalend \\
\hline Elektrotechnici & - & constant \\
\hline Overige commerciële dienstverlening & - & - \\
\hline \multicolumn{3}{|l|}{ Gezondheidszorg } \\
\hline Systeemanalisten & - & sterk dalend \\
\hline Programmeurs & - & constant \\
\hline \multicolumn{3}{|l|}{ Overige kwartaire diensten } \\
\hline Systeemanalisten & - & sterk stijgend \\
\hline Programmeurs & - & sterk dalend \\
\hline Technisch systeemanalisten & - & sterk stijgend \\
\hline Informatici & - & sterk dalend \\
\hline \multicolumn{3}{|l|}{ Onderwijs } \\
\hline Systeemanalisten & - & sterk stijgend \\
\hline Programmeurs & - & sterk stijgend \\
\hline Informatici & - & sterk dalend \\
\hline Elektrotechnici & - & sterk dalend \\
\hline \multicolumn{3}{|l|}{ Overheid } \\
\hline Programmeurs & 2 & sterk stijgend \\
\hline Systeemanalisten & $\overline{1}$ & constant \\
\hline Informatici & - & sterk dalend \\
\hline Technisch systeemanalisten & - & dalend \\
\hline
\end{tabular}

\section{Bron: ROA/CBS}

Het grootste aandeel hebben de informatica-beroepen in de sectoren metaal- en elektrotechniek en in de dienstverlening. In deze bedrijfssectoren zal een eventueel tekort aan mensen met een informatica-opleiding dan ook het meest gevoeld worden. Er zijn ook enkele bedrijfssectoren waar informatica-beroepen (vrijwel) niet voorkomen. Bijvoorbeeld in de landbouw- en visserij, de textielindustrie, de hout- en papierindustrie en in horeca en reparatiebedrijven. Overigens wil dit niet zeggen dat deze bedrijfssectoren geen hinder zouden ondervinden van tekorten aan informatici. Vaak zal in deze sectoren voor automatisering van het produktieproces of de administratie gebruik worden gemaakt van diensten van computerservice- en informatietechnologiebedrijven. Als deze bedrijven grote knelpunten ondervinden in de personeelsvoorziening zullen 
de prijzen van de dienstverlening waarschijnlijk gaan stijgen.

Zoals op basis van de erg hoge bedrijfsectorspreiding verwacht mocht worden, is de beroepsgroep Programmeurs voor de meeste bedrijfssectoren wel van enig belang. Het grootste aandeel heeft deze beroepsgroep echter in het bank- en verzekeringswezen en in de sector communicatie. De beroepsgroep Systeemanalisten heeft vooral een groot aandeel in de werkgelegenheid in de elektrotechniek, de zakelijke dienstverlening en het verzekeringswezen. De Technisch systeemanalisten en de Elektrotechnici zijn met name van belang in de elektrotechniek. Tenslotte is de beroepsgroep Informatici vooral belangrijk in de zakelijke dienstverlening.

Om een goed beeld te kunnen vormen van de mogelijke tekorten die zich voordoen in het informatica-domein moet ook rekening worden gehouden met de conjunctuurgevoeligheid van de werkgelegenheid in dit domein. Als de werkgelegenheid namelijk erg conjunctuurgevoelig is dan kunnen tekorten of overschotten ook mede een gevolg zijn van de conjuncturele situatie. Door een conjuncturele omslag kunnen in dat geval tekorten makkelijk omslaan in overschotten. Met name in de metaal- en elektrotechniek is de conjunctuurgevoeligheid van de werkgelegenheid erg hoog. In de dienstverlening is de conjunctuurgevoeligheid daarentegen over het algemeen erg laag. Tabel 2.10 laat zien dat voor enkele beroepsgroepen in het informatica-domein inderdaad sprake is van een hoge conjunctuurgevoeligheid ${ }^{4}$. Dat geldt voor Elektrotechnici en Systeemanalisten. Voor Technisch systeemanalisten en Informatici is de conjunctuurgevoeligheid van de werkgelegenheid daarentegen laag.

Tabel 2.10

Conjunctuurgevoeligheid per beroepsgroep in het informaticadomein

\begin{tabular}{lcl}
\hline Beroepsgroep & conjunctuurgevoeligheid & typering \\
\hline Programmeurs & 0,82 & gemiddeld \\
Technisch systeemanalisten & 0,54 & laag \\
Systeemanalisten & 1,18 & hoog \\
Elektrotechnici & 1,91 & erg hoog \\
Informatici & 0,51 & laag \\
\hline
\end{tabular}

Bron: ROA

4. De indicator voor conjunctuurgevoeligheid geeft aan in welke mate de werkgelegenheid in een beroepsgroep fluctueert als gevolg van schommelingen in de werkgelegenheid in bedrijfssectoren. Naarmate de waarde van deze indicator hoger is, fluctueert de werkgelegenheid sterker (zie ook Borghans, e.a., 1995). 


\section{De arbeidsmarktpositie van informatici: Recente ontwikkelingen en actuele situatie}

\subsection{Inleiding}

Lang niet alle werkenden in het informatica-domein hebben een informatica-opleidingsachtergrond. Toen de werkgelegenheid in informatica-beroepen opkwam was het aanbod van reguliere opleidingen nog heel beperkt waardoor veel mensen met een andere opleidingsachtergrond zijn aangetrokken. De laatste jaren is dit aanbod sterk uitgebreid en we zie ook dat het aantal werkenden met een informatica-opleiding toeneemt. In dit hoofstuk zal nader worden ingegaan op degenen die een informaticaopleiding hebben afgerond. In paragraaf 3.2 worden eerst de recente ontwikkelingen in de werkgelegenheid geschetst. Vervolgens wordt in paragraaf 3.3 ingegaan op de arbeidsmarktpositie van schoolverlaters van informatica-opleidingen. Paragraaf 3.4 geeft een beeld van de beloning van werkenden die een informatica-opleiding hebben afgerond.

\subsection{Werkgelegenheidsontwikkelingen}

Het aantal werkenden met een informatica-opleiding is, zoals al bleek in hoofdstuk 2, gering in vergelijking met het aantal werkenden in het informatica-domein. Gemiddeld genomen over 1995 en 1996 zijn er ongeveer 70 duizend mensen met een informaticaopleiding werkzaam. Dit is nog niet de helft van het totaal aantal werkenden in het informatica-domein. Wel blijkt het aantal werkenden met een informatica-opleiding de laatste jaren flink toe te nemen.

Tabel 3.1

Aantallen werkzame informatici naar opleidingstype, gemiddelde 1995-1996

Opleidingstype

$\begin{array}{lr}\text { MBO/LLW automatisering } & 34.500 \\ \text { HBO informatica } & 36.000 \\ \text { WO informatica en bestuurlijke informatiekunde } & 7.000\end{array}$

Bron:CBS/ROA

Tabel 3.2 laat zien dat het aantal werkenden met een informatica-opleiding op WOniveau in vier jaar tijd bijna verdubbeld is. Ook het aantal werkenden met een opleiding $\mathrm{HBO}$ informatica is fors toegenomen. Voor het opleidingstype MBO/LLW automatisering was de werkgelegenheidsgroei wat lager dan voor HBO en WO informatica maar toch nog steeds aanzienlijk. Deze werkgelegenheidsgroei voor personen met een informatici-opleiding is bovendien veel groter dan de groei van de totale werkgelegenheid in het informatica-domein. Dit betekent dat er binnen de informatica-beroepen een toename is geweest van het werkgelegenheidsaandeel van mensen met een 
informatica-opleiding. Dit wijst er op dat bij een toenemend aanbod van informatici arbeidskrachten met een andere opleidingachtergrond weer verdrongen worden, omdat werkgevers kennelijk toch een voorkeur hebben voor arbeidskrachten met een informatica-opleidingsachtergrond.

Tabel 3.2

Groei van de werkgelegenheid voor informatici tussen 1992-1996

\begin{tabular}{lc} 
Opleidingstype & $\%$ \\
\hline MBO/LLW automatisering & 16 \\
HBO informatica & 25 \\
WO informatica en bestuurlijkeinformatiekunde & 97 \\
\hline
\end{tabular}

Bron:CBS/ROA

Uit figuur 3.1 blijkt dat dit met name heeft gespeeld bij WO-informatica en bestuurlijke informatiekunde. De figuur geeft per opleidingstype de feitelijke werkgelegenheidsontwikkeling en de werkgelegenheidsontwikkeling als het aandeel constant zou zijn gebleven in de periode 1992-1996. In het laatste geval gaat het om de werkgelegenheidsontwikkeling voor een opleidingstype als gevolg van veranderingen in de werkgelegenheidsontwikkelingen in verschillende beroepen. De feitelijke werkgelegenheidsgroei kan hier vanaf wijken omdat het werkgelegenheidsaandeel van werkenden met dit opleidingstype binnen beroepen kan toe- of afnemen.

Op basis van alleen de werkgelegenheidsgroei in de beroepen waar personen met een universitaire informatica-opleiding werkzaam zijn, zou de werkgelegenheid voor WO informatica en bestuurlijke informatiekunde in de periode 1992-1996 vrijwel constant zijn gebleven. Ook bij HBO informatica is de werkgelegenheid meer gestegen dan alleen op basis van de werkgelegenheidsgroei in de beroepen zou worden verwacht, al is het verschil minder groot dan bij WO informatica en bestuurlijke informatiekunde. De werkgelegenheidsgroei bij MBO/LLW automatisering is daarentegen in een aantal jaren wat lager dan zou worden verwacht op basis van alleen de beroepsgroei. Dat betekent dat het werkgelegenheidsaandeel van mensen met een informatica-opleiding op middelbaar niveau niet is toegenomen. 
Figuur 3.1

Werkgelegenheidsontwikkeling informatica-opleidingen naar opleidingsniveau, 1992-1996
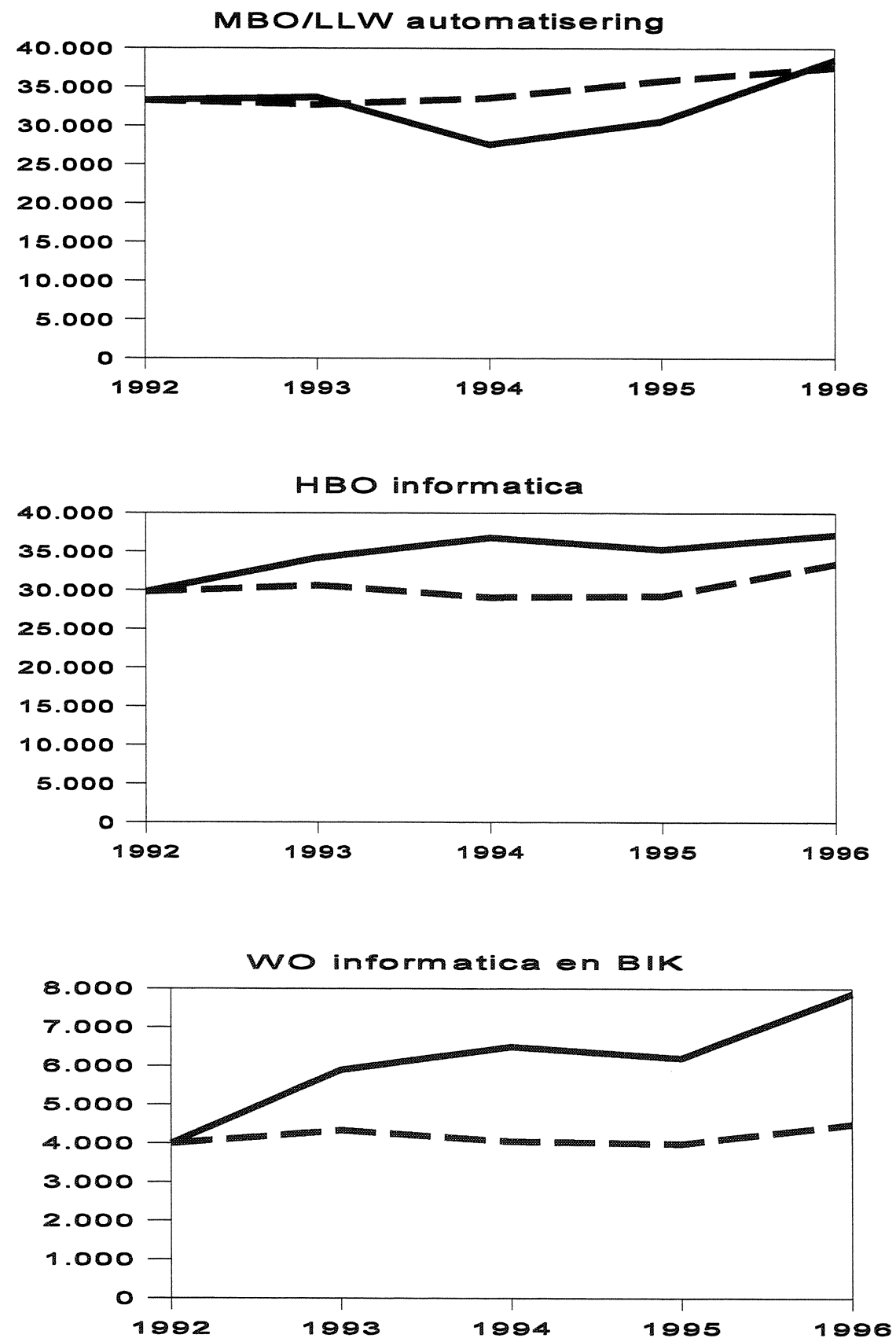

feitelijke werkgelegenheid

- - - werkgelegenheid bij een gelijkblijvend aandeel in de totale werkgelegenheid in (informatica-)beroepen 


\subsection{Recent afgestudeerden van informatica-opleidingen}

Op basis van de enquêtes HBO-Monitor en WO-Monitor kan een beeld gegeven worden van de arbeidsmarktpositie van recent afgestudeerden van informatica-opleidingen ${ }^{5}$. Voor HBO informatica zijn gegevens beschikbaar vanaf 1992 zodat ook inzicht wordt verkregen in de jaarlijkse ontwikkelingen. Waar mogelijk zijn de gegevens voor HBO informatica verder verbijzonderd naar specifieke studierichtingen. Op WO-niveau zijn voor 1996 alleen gegevens beschikbaar voor de opleidingen WO bestuurlijke informatica en WO technische informatica. Beide opleidingen worden gerekend tot het opleidingstype WO informatica en bestuurlijke informatiekunde maar omdat geen gegevens beschikbaar zijn over afgestudeerden van andere informatica-opleidingen die tot dit opleidingstype worden gerekend is het niet mogelijk om een volledig beeld te geven van de arbeidsmarktsituatie van de afgestudeerden van de informaticaopleidingen op WO-niveau.

Om inzicht te krijgen in de arbeidsmarktpositie van verschillende informaticaopleidingen zullen we kijken naar de werkloosheid onder recent afgestudeerden, de intredewerkloosheid, het percentage recent afgestudeerden dat werkzaam is in een functie onder het eigen opleidingsniveau en het percentage dat buiten de eigen vakrichting werkzaam is ${ }^{6}$.

\section{HBO informatica}

Allereerst kijken we naar het werkloosheidspercentage bij recent afgestudeerden. Het gaat hier om personen die werkloos waren op het moment dat de enquête werd afgenomen. Tabel 3.3 laat zien dat de werkloosheid onder afgestudeerden van informatica-opleidingen op HBO-niveau de laatste jaren aanzienlijk is gedaald. De werkloosheidsdaling is voor de informatica-opleidingen bovendien groter dan voor het totale HBO.

Hetzelfde geldt voor de intredewerkloosheid. Uit tabel 3.3 blijkt dat tussen 1992 en 1994 het percentage dat na het afstuderen langer dan drie maanden werkloos is geweest hoger was dan gemiddeld voor het HBO. Vanaf 1994 daalt het percentage echter aanzienlijk tot onder het gemiddelde voor het HBO. Van de afgestudeerde informatici

5. Omdat veel informatica-opleidingen op MBO-niveau niet regulier zijn en via de enquêtes alleen schoolverlaters van reguliere opleidingen worden benaderd zijn er helaas te weinig gegevens beschikbaar om ook een beeld te geven van de arbeidsmarktpositie van schoolverlaters uit de richting MBO/LLW automatisering.

6. Of iemand wordt onderbenut of werkzaam is buiten de eigen vakrichting wordt bepaald door aan de afgestudeerde te vragen welk niveau en welke opleidingsrichting door de werkgever vereist werd. Bij richting gaan we er vanuit dat als een afgestudeerde aangeeft dat een andere of geen speciale opleidingsrichting werd vereist, hij of zij buiten de eigen vakrichting werkzaam is. 
die in 1996 zijn geënquêteerd is nog maar 6\% langer dan 3 maanden werkloos geweest. Overigens zijn er wel enige verschillen waar te nemen tussen de onderscheiden informatica-opleidingen op HBO-niveau. $\mathrm{Zo}$ is het percentage met een intredewerkloosheid van langer dan 3 maanden bij afgestudeerden van de opleiding HBO hogere informatica systematisch hoger dan bij de andere informatica-opleidingen. Bij HBO Bedrijfskundige informatica is dit percentage juist altijd lager dan bij de andere informatica-opleidingen. Overigens is het wel opvallend dat afgestudeerden die een deeltijdopleiding hebben gevolgd in 1996 wel vaker langer dan drie maanden werkloos zijn geweest na afstuderen dan gemiddeld voor HBO-deeltijd het geval is.

Tabel 3.3

Percentage recent afgestudeerden dat als werkloos geregistreerd staat, 1992-1996

\begin{tabular}{lrrrrr}
\hline Opleiding & $\begin{array}{r}1992 \\
\%\end{array}$ & $\begin{array}{r}1993 \\
\%\end{array}$ & $\begin{array}{r}1994 \\
\%\end{array}$ & $\begin{array}{r}1995 \\
\%\end{array}$ & $\begin{array}{r}1996 \\
\%\end{array}$ \\
\hline HBO Computertechniek & & & & & 4 \\
HBO Hogere informatica & 8 & 8 & 10 & 9 & 2 \\
HBO Informatica en informatiekunde & 5 & 28 & 9 & 1 & 0 \\
HBO Bedrijfskundige informatica & 13 & 17 & 6 & 0 & 2 \\
HBO Communicatiesystemen &. &. &. &. & 0 \\
HBO informatica voltijd & 10 & 15 & 8 & 4 & 2 \\
HBO totaal voltijd & 10 & 12 & 10 & 6 & 6 \\
HBO informatica deeltijd & 0 & 5 & 2 & 2 & 0 \\
HBO totaal deeltijd & 4 & 3 & 3 & 4 & 5 \\
Bron: ROA (HBO-Monitor) & & & & &
\end{tabular}

Tabel 3.4

Percentage recent afgestudeerden dat langer dan 3 maanden werkloos is geweest na afstuderen, 1992-1996

\begin{tabular}{lrrrrr}
\hline Opleiding & $\begin{array}{r}1992 \\
\%\end{array}$ & $\begin{array}{r}1993 \\
\%\end{array}$ & $\begin{array}{r}1994 \\
\%\end{array}$ & $\begin{array}{r}1995 \\
\%\end{array}$ & $\begin{array}{r}1996 \\
\%\end{array}$ \\
\hline HBO Computertechniek & & & & & 10 \\
HBO Hogere informatica & 23 & 17 & 31 & 19 & 8 \\
HBO Informatica en informatiekunde & 16 & 42 & 16 & 5 & 4 \\
HBO Bedrijfskundige informatica & 13 & 17 & 17 & 11 & 3 \\
HBO Communicatiesystemen &. & $\cdot$ & $\cdot$ &. & 0 \\
HBO informatica voltijd & 17 & 21 & 23 & 13 & 6 \\
HBO totaal voltijd & 15 & 18 & 19 & 16 & 9 \\
HBO informatica deeltijd & 10 & 19 & 3 & 2 & 12 \\
HBO totaal deeltijd & 8 & 7 & 7 & 7 & 8 \\
\hline Bron: ROA (HBO-Monitor) & & & & &
\end{tabular}


Tabel 3.5 laat zien dat het percentage dat werkzaam is onder het eigen opleidingsniveau bij afgestudeerden van de voltijdse informatica-opleidingen structureel lager is dan bij afgestudeerden uit andere richtingen. Bovendien is deze zogenaamde onderbenutting de laatste jaren afgenomen. Bij de afgestudeerden van informatica-opleidingen was in 1996 slechts $6 \%$ in een beroep werkzaam waarvoor een lager opleidingsniveau dan $\mathrm{HBO}$ vereist was, tegenover $23 \%$ van de afgestudeerden van alle voltijds $\mathrm{HBO}$ opleidingen. Het opleidingsniveau van afgestudeerden van deeltijdopleidingen wordt overigens relatief vaker onderbenut. Een mogelijke verklaring hiervoor is dat veel van deze afgestudeerden al in het beroep werkzaam waren voor dat ze aan de opleiding begonnen. Als ze de opleiding eenmaal hebben afgerond zijn ze te hoog gekwalificeerd voor dit beroep, maar er zal enige tijd overheen gaan voordat ze, bijvoorbeeld door promotie, een beroep op een hoger niveau krijgen.

Tabe/ 3.5

Percentage recent afgestudeerden dat werkzaam is in een beroep onder HBO-niveau, 1992-1996

\begin{tabular}{lrrrrr}
\hline Opleiding & $\begin{array}{r}1992 \\
\%\end{array}$ & $\begin{array}{r}1993 \\
\%\end{array}$ & $\begin{array}{r}1994 \\
\%\end{array}$ & $\begin{array}{r}1995 \\
\%\end{array}$ & $\begin{array}{r}1996 \\
\%\end{array}$ \\
\hline HBO Computertechniek & & & & & 9 \\
HBO Hogere informatica & 13 & 12 & 6 & 4 & 8 \\
HBO Informatica en informatiekunde & 5 & 12 & 6 & 3 & 5 \\
HBO Bedrijfskundige informatica & 9 &. &. &. & 13 \\
HBO Communicatiesystemen & 9 & 11 & 9 & 6 & 6 \\
HBO informatica voltijd & 19 & 22 & 22 & 21 & 23 \\
HBO totaal voltijd & 3 & 24 & 31 & 12 & 15 \\
HBO informatica deeltijd & 27 & 27 & 29 & 25 & 26 \\
HBO totaal deeltijd & & & & &
\end{tabular}

Bron: ROA (HBO-Monitor)

Ten slotte kijken we naar het percentage recent afgestudeerden dat werkzaam is buiten de eigen vakrichting. Met uitzondering van het jaar 1993 ligt dat percentage voor afgestudeerden van voltijdse informatica-opleidingen systematisch lager dan gemiddeld voor het HBO. Wel neemt het percentage dat buiten de eigen vakrichting werkzaam is de laatste jaren wat toe. Afgestudeerden van deeltijd informatica-opleidingen op HBOniveau zijn over het algemeen vaker dan gemiddeld buiten hun eigen richting werkzaam. Ook hier geldt echter weer dat veel deeltijders waarschijnlijk al een baan hadden voor ze aan de opleiding begonnen zijn en na het voltooien van die opleiding niet meteen kunnen switchen naar een functie die beter aansluit bij hun opleiding. 
Tabel 3.6

Percentage recent afgestudeerden dat werkzaam is in een beroep buiten de eigen vakrichting, 1992-1996

\begin{tabular}{lrrrrr}
\hline Opleiding & $\begin{array}{r}1992 \\
\%\end{array}$ & $\begin{array}{r}1993 \\
\%\end{array}$ & $\begin{array}{r}1994 \\
\%\end{array}$ & $\begin{array}{r}1995 \\
\%\end{array}$ & $\begin{array}{r}1996 \\
\%\end{array}$ \\
\hline HBO Computertechniek & & & & & 9 \\
HBO Hogere informatica & 3 & 20 & 11 & 13 & 16 \\
HBO Informatica en informatiekunde & 5 & 16 & 11 & 14 & 12 \\
HBO Bedrijfskundige informatica & 13 & 16 & 13 & 13 & 19 \\
HBO Communicatiesystemen &. &. &. &. & 20 \\
HBO informatica & 8 & 20 & 13 & 14 & 16 \\
HBO totaal voltijd & 13 & 18 & 20 & 22 & 20 \\
HBO informatica deeltijd & 20 & 26 & 17 & 20 & 13 \\
HBO totaal deeltijd & 15 & 13 & 15 & 16 & 12 \\
\hline Bron: ROA (HBO-Monitor) & & & & &
\end{tabular}

\section{WO informatica en bestuurlijke informatiekunde}

Zoals gezegd is op WO-niveau alleen informatie beschikbaar voor de opleidingen WO bestuurlijke informatiekunde en WO technische informatica. Het is daarom niet mogelijk om een representatief beeld te geven van de arbeidsmarktpositie van alle recent afgestudeerden met een informatica-opleiding op WO-niveau. Natuurlijk geeft de situatie bij de twee genoemde opleidingen wel een indicatie voor de arbeidsmarktpositie van informatici op WO-niveau. Als referentie worden ook steeds de cijfers voor het totaal WO technisch en totaal WO economisch gepresenteerd.

Tabe/ 3.7

Werkloosheid onder afgestudeerden, 1996

\begin{tabular}{lcc}
\hline Opleiding & $\begin{array}{c}\text { geregistreerde } \\
\text { werkloosheid } \\
\%\end{array}$ & $\begin{array}{c}\text { langer dan 3 maanden } \\
\text { werkloos na afstuderen } \\
\%\end{array}$ \\
\hline WO bestuurlijke informatiekunde & 3 & 6 \\
WO technische informatica & 0 & 12 \\
WO economisch & 4 & 13 \\
WO technisch & 5 & 22
\end{tabular}

Bron: ROA (WO-Monitor)

Uit tabel 3.7 blijkt dat de werkloosheid onder afgestudeerden van zowel de opleiding WO bestuurlijke informatiekunde als WO technische informatica relatief laag is. De geregistreerde werkloosheid is bij WO technische informatica zelfs nul. Wel is de intredewerkloosheid bij WO technische informatica hoog. De intredewerkloosheid bij andere technische WO-richtingen blijkt gemiddeld echter nog hoger te zijn. Verder blijkt 
uit tabel 3.8 dat de onderbenutting voor beide informatica-opleidingen erg hoog is.

Tabel 3.8

Aansluiting opleiding/beroep naar niveau en richting, 1996

\begin{tabular}{lcc}
\hline & $\begin{array}{c}\text { Onderbenutting } \\
\%\end{array}$ & $\begin{array}{c}\text { Buiten eigen vakrichting } \\
\text { werkzaam } \\
\%\end{array}$ \\
\hline WO bestuurlijke informatiekunde & 58 & 15 \\
WO technische informatica & 77 & 18 \\
WO economisch & 48 & 23 \\
WO technisch & 39 & 16 \\
\hline
\end{tabular}

Bron: ROA (WO-Monitor)

Opmerkelijk is dat bij WO technische informatica meer dan drie kwart van de recent afgestudeerden aangeeft in een beroep te werken waarvoor een lager niveau dan WOniveau vereist was en bij WO bestuurlijke informatiekunde is dat bijna $60 \%$. Het percentage afgestudeerden dat zegt in een beroep werkzaam te zijn waarvoor de eigen of een aanverwante studierichting niet was vereist, is daarentegen juist relatief laag. Afgestudeerden komen dus meestal wel in de eigen vakrichting terecht maar vaak in een baan op een lager niveau.

\subsection{Beloning van informatici}

Op basis van de arbeidsmarktgegevens over de recent afgestudeerden van de informatica-opleidingen die in de vorige paragraaf gepresenteerd zijn, kan geconcludeerd worden dat de arbeidsmarktpositie van de informatica-opleidingen de laatste jaren erg goed is geworden. In deze paragraaf zal worden nagegaan of de goede arbeidsmarktpositie ook tot uiting komt in de beloning van informatici.

Tabel 3.9

Gemiddeld bruto maandloon van recent afgestudeerde HBO'ers, 1996*

\begin{tabular}{lll}
\hline Opleiding & $\begin{array}{c}\text { gemiddeld loon } \\
\text { in guldens }\end{array}$ \\
\hline HBO computertechniek & 3.174 & $(731)$ \\
HBO hogere informatica & 3.353 & $(542)$ \\
HBO informatica en informatiekunde & 3.782 & $(474)$ \\
HBO bedrijfskundige informatica & 3.546 & $(965)$ \\
HBO communicatiesysteem & $3.322(992)$ \\
HBO informatica & $3.468 \quad(718)$ \\
HBO totaal & $3.266(1.225)$ \\
\hline
\end{tabular}

Bron: ROA (HBO-Monitor)

${ }^{*}$ standaarddeviatie tussen haakjes 
Tabel 3.9 laat zien dat het gemiddelde bruto maandloon voor afgestudeerden uit de richting $\mathrm{HBO}$ informatica hoger ligt dan gemiddeld voor het $\mathrm{HBO}$. Het zijn met name afgestudeerden van de opleidingen HBO informatica en informatiekunde en HBO bedrijfskundige informatica die een relatief hoog loon verdienen. Afgestudeerden van de opleiding HBO computertechniek verdienen daarentegen wat minder dan gemiddeld. Geconcludeerd kan worden dat de gunstige arbeidsmarktsituatie voor informatici wat betreft de kwantitatieve en kwalitatieve aansluiting op de arbeidsmarkt ook wordt weerspiegeld in een hoger loon. 


\section{Opleidingsachtergrond van werkenden in het informatica-domein}

\subsection{Inleiding}

In hoofstuk 3 werd duidelijk dat het percentage werkenden met een informaticaopleiding binnen het informatica-domein relatief gering is. In dit hoofdstuk zullen we dieper ingaan op de opleidingsachtergrond van werkenden in het informatica-domein. Allereerst zal in paragraaf 4.2 worden bekeken wat de belangrijkste opleidingstypes zijn voor de diverse beroepsgroepen binnen het informatica-domein. Bovendien zal worden nagegaan in welke mate het mogelijk is om tussen opleidingstypes te substitueren. In paragraag 4.3 zal vervolgens de instroom van schoolverlaters in het informatica-domein in beeld worden gebracht. Nagegaan zal worden of schoolverlaters die geen informatica-opleiding hebben gevolgd vaker aansluitingsproblemen ondervinden dan schoolverlaters die wel een informatica-opleiding hebben gevolgd en of deze aansluitingsproblemen er toe leiden dat deze schoolverlaters vaker aanvullende informatica-cursussen volgen. Ten slotte zal ook de beloning van afgestudeerden die werkzaam zijn in informatica-beroepen nader worden geanalyseerd.

\subsection{Substitutiemogelijkheden tussen opleidingen}

De substitutiemogelijkheden tussen arbeidskrachten met uiteenlopende opleidingsachtergronden in het informatica-domein verschillen sterk tussen de beroepsgroepen, zoals tabel 4.1 laat zien. In de beroepsgroep Technisch systeemanalisten zijn de substitutiemogelijkheden zeer beperkt. In de beroepsgroepen Systeemanalisten en Informatici zijn juist veel substitutiemogelijkheden. Deze beroepsgroepen zijn dus minder afhankelijk van de arbeidsmarktinstroom van een beperkt aantal opleidingen dan de andere beroepsgroepen in het informatica-domein. Knelpunten als gevolg van tekorten bij een opleiding zullen daarom in deze beroepsgroepen makkelijker kunnen worden opgelost.

Tabel 4.1

Substitutiemogelijkheden tussen mensen met uiteenlopende opleidingsachtergronden per beroepsgroep in het informatica-domein, gemiddelde 1995-1996

\begin{tabular}{lcl}
\hline Beroepsgroep & Spreidingsindex & Typering \\
\hline Programmeurs & 8,51 & gemiddeld \\
Technisch systeemanalisten & 5,28 & laag \\
Systeemanalisten & 10,69 & hoog \\
Elektrotechnici & 6,35 & gemiddeld \\
Informatici & 16,36 & erg hoog \\
\hline
\end{tabular}


Tabel 4.2

Belangrijkste opleidingstypen per beroepsgroep, als percentage van het totaal aantal werkenden in de beroepsgroep, gemiddelde 1995-1996

\begin{tabular}{|c|c|c|}
\hline Beroepsgroep & $\%$ & $\begin{array}{l}\text { trend } \\
1992-1996\end{array}$ \\
\hline $\begin{array}{l}\text { Programmeurs } \\
\text { MBO/LLW automatisering } \\
\text { HAVO/NWO } \\
\text { MBO/LLW elektrotechniek } \\
\text { MAVO } \\
\text { MBO/LLW administratie }\end{array}$ & $\begin{array}{l}20 \\
19 \\
11 \\
11 \\
10\end{array}$ & $\begin{array}{l}\text { dalend } \\
\text { constant } \\
\text { stijgend } \\
\text { constant } \\
\text { stijgend }\end{array}$ \\
\hline $\begin{array}{l}\text { Technisch systeemanalisten } \\
\text { HBO elektrotechniek } \\
\text { HBO informatica } \\
\text { MBO/LLW elektrotechniek } \\
\text { HBO werktuigbouwkunde }\end{array}$ & $\begin{array}{r}31 \\
28 \\
- \\
-\end{array}$ & $\begin{array}{l}\text { constant } \\
\text { sterk stijgend } \\
\text { stijgend } \\
\text { dalend }\end{array}$ \\
\hline $\begin{array}{l}\text { Systeemanalisten } \\
\text { HBO informatica } \\
\text { HBO elektrotechniek } \\
\text { HAVO/NWO } \\
\text { MBO/LLW automatisering }\end{array}$ & $\begin{array}{r}26 \\
9 \\
8 \\
5\end{array}$ & $\begin{array}{l}\text { constant } \\
\text { constant } \\
\text { dalend } \\
\text { dalend }\end{array}$ \\
\hline $\begin{array}{l}\text { Elektrotechnici } \\
\text { WO elektrotechniek } \\
\text { HBO elektrotechniek } \\
\text { WO wiskunde en natuurwetenschappen } \\
\text { WO informatica en bestuurlijke informatiekunde } \\
\text { MBO/LLW elektrotechniek } \\
\text { WO werktuigbouwkunde }\end{array}$ & $\begin{array}{l}- \\
- \\
- \\
-\end{array}$ & $\begin{array}{l}\text { sterk dalend } \\
\text { stijgend } \\
\text { sterk stijgend } \\
\text { sterk stijgend } \\
\text { sterk stijgend } \\
\text { - }\end{array}$ \\
\hline $\begin{array}{l}\text { Informatici } \\
\text { WO wiskunde en natuurwetenschappen } \\
\text { WO informatica en bestuurlijke informatiekunde } \\
\text { HBO informatica } \\
\text { WO sociale wetenschappen } \\
\text { WO bedrijfskunde } \\
\text { WO econom(etr)ie } \\
\text { HAVONWO } \\
\text { WO elektrotechniek }\end{array}$ & $\begin{array}{l}- \\
- \\
- \\
- \\
- \\
-\end{array}$ & $\begin{array}{l}\text { constant } \\
\text { sterk stijgend } \\
\text { dalend } \\
\text { dalend } \\
\text { stijgend } \\
\text { constant } \\
\text { dalend } \\
\text { sterk stijgend }\end{array}$ \\
\hline
\end{tabular}

Bron: CBS/ROA

Tabel 4.2 geeft een overzicht van de belangrijkste opleidingstypes per beroepsgroep in het informatica-domein. Zoals ook in hoofstuk 3 al bleek is het aandeel van de informatica-opleidingen in de meeste beroepsgroepen vrij klein. In de beroepsgroep Programmeurs heeft $20 \%$ van de werkenden een opleiding gevolgd die valt onder MBO/LLW automatisering. Het aandeel van mensen met een HAVO of WWO opleiding is ongeveer even groot. Verder zijn de opleidingstypen MAVO, MBO/LLW elektrotechniek en $M B O / L L W$ administratie elk goed voor ongeveer $10 \%$ van de werkgelegenheid. De belangrijkste opleidingstypes voor de beroepsgroep Technisch systeemanalisten vormen de opleidingstypes HBO elektrotechniek en HBO informatica. Ongeveer $60 \%$ van het totaal aantal werkenden in deze beroepsgroep heeft een van deze twee 
opleidingsachtergronden. Daarnaast heeft ook een deel van de werkenden een opleiding MBO/LLW elektrotechniek of een opleiding $H B O$ werktuigbouwkunde gevolgd.

Ruim een kwart van de werkenden in de beroepsgroep Systeemanalisten heeft een informatica-opleiding op HBO-niveau afgesloten. Andere belangrijke opleidingstypes voor deze beroepsgroep zijn HBO elektrotechniek, HAVO en VWO en MBO/LLW automatisering. Bijna de helft van de werkenden in de beroepsgroep Elektrotechnici heeft een opleiding elektrotechniek op HBO of WO niveau gevolgd. Daarnaast komen ook de opleidingstypes $H B O$ wiskunde en natuurwetenschappen en WO informatica en bestuurlijke informatiekunde in deze beroepsgroep voor. De opleidingstypen WO Informatica en bestuurlijke informatiekunde, WO wiskunde en natuurwetenschappen zijn samen goed voor bijna een kwart van de werkgelegenheid in de beroepsgroep Informatici. Verder is er een groot aantal opleidingen die elk een klein aandeel van de werkgelegenheid uitmaken. Dit verklaart tevens de vele substitutiemogelijkheden in deze beroepsgroep.

Tabel 4.3

Instroom van schoolverlaters uit het regulier onderwijs in het informatica-domein per beroepsgroep, 1996

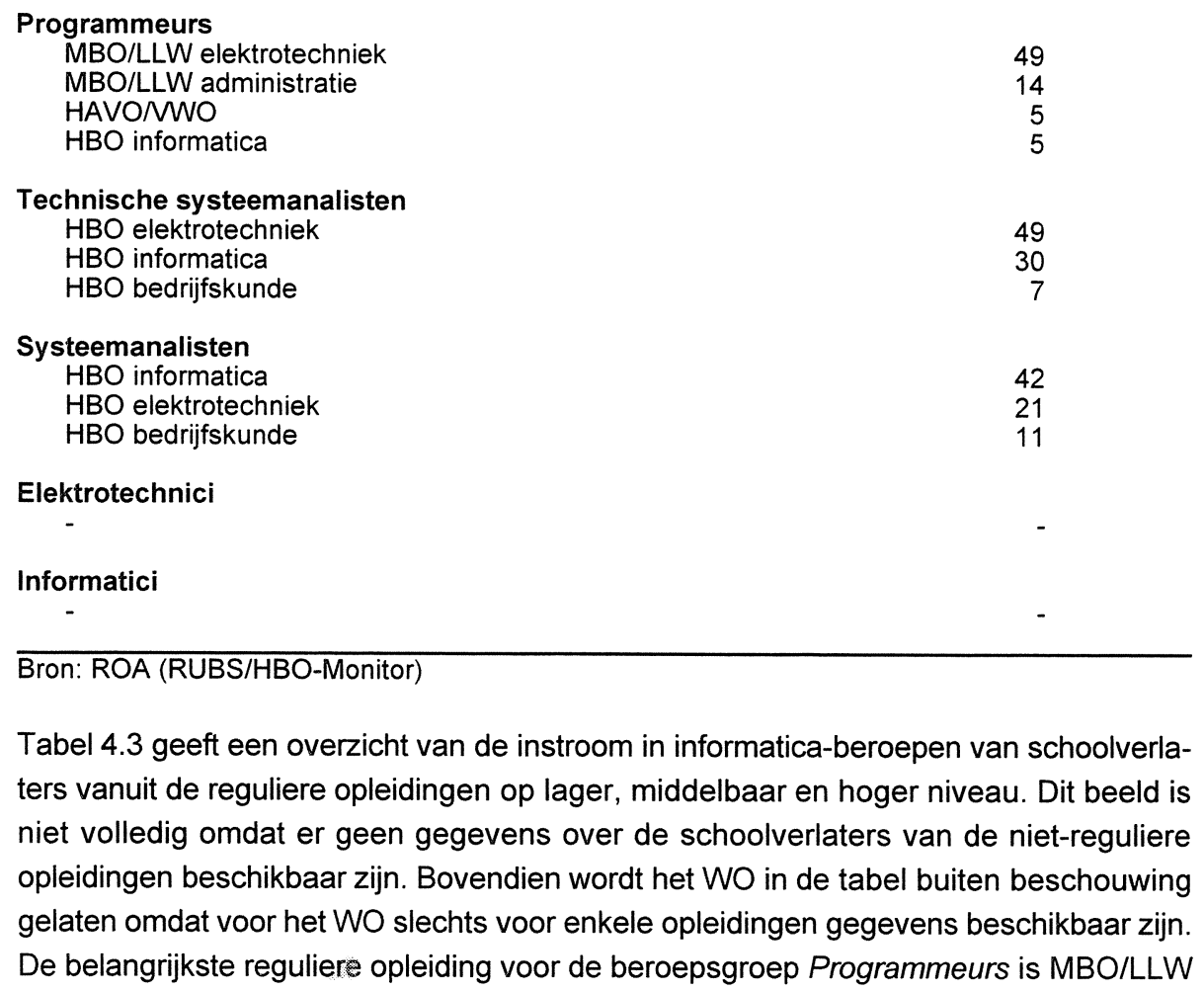


elektrotechniek. Bijna de helft van de instroom van schoolverlaters vanuit het regulier onderwijs in deze beroepsgroep heeft deze opleidingsachtergrond. Daarnaast heeft bijna $15 \%$ een opleiding administratie in het $\mathrm{MBO}$ of $\mathrm{KMBO}$.

De opleidingsachtergrond van de instroom van schoolverlaters in de beroepsgroep Technisch systeemanalisten komt grotendeels overeen met de opleidingsachtergrond van alle werkenden in deze beroepsgroep. De belangrijkste opleidingstypes zijn $\mathrm{HBO}$ elektrotechniek en $\mathrm{HBO}$ informatica. Wel is nu het aandeel van de schoolverlaters van de opleiding HBO elektrotechniek een stuk hoger dan het aandeel van HBO informatica. Ongeveer $40 \%$ van de schoolverlaters die gaan werken in de beroepsgroep Systeemanalisten heeft een opleiding $\mathrm{HBO}$ informatica afgerond, $20 \%$ een opleiding $\mathrm{HBO}$ elektrotechniek en $11 \%$ een opleiding HBO bedrijfskunde. Voor de overige beroepsgroepen in het informatica-domein - Elektrotechnici en Informatici - is de instroom van schoolverlaters op MBO- en HBO-niveau te klein om een betrouwbaar beeld te kunnen geven.

\subsection{Aansluiting tussen opleiding en beroep in het informatica-domein}

Een aanzienlijk deel van de schoolverlaters en recent afgestudeerden die in het informatica-domein instromen heeft, zoals duidelijk werd uit tabel 4.3, geen informaticaopleidingsachtergrond. In deze paragraaf zal worden nagegaan of degenen die in het informatica-domein instromen zonder een informatica-opleidingsachtergrond vaker problemen ervaren in de aansluiting tussen hun opleiding en de functie die zij uitoefenen, dan degenen die wel een informatica-opleiding hebben gevolgd. Omdat alleen op HBO-niveau zowel de informatica-opleidingen als de overige opleidingsrichtingen goed vertegenwoordigd zijn beperken we ons hier tot recent afgestudeerde HBO'ers.

Tabel 4.4

Percentage recent afgestudeerde HBO'ers werkzaam in het informatica-domein dat vindt dat de aansluiting tussen opleiding en beroep matig tot slecht is, 1996

\begin{tabular}{lc}
\hline Opleidingstype & $\%$ \\
\hline HBO informatica & 10 \\
HBO overig & 22 \\
chi-kwadraat toets op verschil & $23,6^{\star *}$ \\
${ }^{\star *}=$ significant bij 1\%-niveau & \\
\hline Bron: ROA (HBO-Monitor) &
\end{tabular}

Uit tabel 4.4 blijkt dat afgestudeerden zonder informatica-opleidingsachtergrond inderdaad vaker zeggen dat de aansluiting tussen de gevolgde opleiding en hun huidige beroep matig tot slecht is. Van degenen die geen informatica-opleiding hebben gevolgd vindt $22 \%$ de aansluiting matig of slecht tegenover slechts $10 \%$ van degenen die wel 
een informatica-opleiding hebben gevolgd. Dit betekent overigens ook dat maar liefst viervijfde van de afgestudeerden zonder informatica-opleiding de aansluiting redelijk tot goed vindt. De meerderheid ervaart dus geen knelpunten in de aansluiting tussen opleiding en beroep.

Verwacht mag worden dat degenen die geen informatica-opleiding hebben gevolgd vooral vaker knelpunten ondervinden doordat hun vaktechnische kennis en vaardigheden tekort schieten. Om na te gaan in hoeverre dat inderdaad het geval is hebben we gekeken naar het belang van vaktechnische kennis en vaardigheden voor een goede uitoefening van de functies in het informatica-beroependomein en de knelpunten die op dat gebied worden ervaren?

Tabel 4.5

Percentage recent afgestudeerde HBO'ers werkzaam in het informatica-domein dat zegt dat vaktechnische kennis- en vaardigheden van belang zijn voor een goede uitoefening van hun functie, 1996

\begin{tabular}{lccc}
\hline & $\begin{array}{c}\mathrm{HBO} \text { informatica } \\
\%\end{array}$ & $\begin{array}{c}\mathrm{HBO} \text { overig } \\
\%\end{array}$ & chi-kwadraat toets \\
\hline $\begin{array}{l}\text { Vakkennis } \\
\begin{array}{l}\text { Vakspecifieke methoden en } \\
\text { technieken }\end{array}\end{array}$ & 83 & 68 & $27,8^{\star *}$ \\
$\begin{array}{l}\text { Recente ontwikkelingen in het } \\
\text { vakgebied }\end{array}$ & 71 & 67 & 2,4 \\
$\begin{array}{l}\text { Inzicht in informatie- en } \\
\text { communicatietechnologie }\end{array}$ & 77 & 75 & 0,7 \\
$\begin{array}{l}\text { Toepassen van (theoretische) } \\
\text { kennis en technieken in de praktijk }\end{array}$ & 84 & 88 & 3,4 \\
$\begin{array}{l}\text { Analytische en diagnostische } \\
\text { (onderzoeks)vaardigheden }\end{array}$ & 73 & 63 & $11,8^{\star *}$ \\
$\begin{array}{l}\text { Kwantitatieve onderzoeks- } \\
\text { vaardigheden }\end{array}$ & 70 & 70 & 0,0 \\
**=significant bij 1\%-niveau & 30 & 42 & $16,8^{\star *}$ \\
\hline Bron: ROA (HBO-Monitor) & & &
\end{tabular}

Tabel 4.5 geeft een overzicht van het belang van verschillende aspecten van de vaktechnische kennis en vaardigheden voor de uitoefening van de functies in het informatica-beroependomein. De tabel laat zien dat er slechts voor enkele aspecten een significant verschil is tussen recent afgestudeerden met en zonder een informaticaopleiding. Degenen die een informatica-opleiding hebben gevolgd geven vaker aan dat vakkennis belangrijk is voor het uitoefenen van hun functie. Ook zeggen ze vaker dat het toepassen van theoretische kennis en technieken in de praktijk van belang is. Dat betekent dat degenen die een informatica-opleiding hebben gevolgd dus vaker in

7. Deze informatie wordt ontleend aan uitspraken van de schoolverlaters over de aspecten waaraan hun opleiding meer aandacht had moeten besteden. 
functies terecht komen die hoge eisen aan de vakkennis stellen. Tenslotte valt op dat personen die geen informatica-opleiding hebben gevolgd vaker in informatica-beroepen werken waarvoor kwantitatieve onderzoeksvaardigheden van belang zijn.

Tabel 4.6

Percentage recent afgestudeerde HBO'ers werkzaam in het informatica-domein dat in hun opleiding meer aandacht had willen besteden aan bepaalde vaktechnische kennis en vaardigheden, 1996

\begin{tabular}{lccc}
\hline & $\begin{array}{c}\text { HBO informatica } \\
\%\end{array}$ & $\begin{array}{c}\text { HBO overig } \\
\%\end{array}$ & $\begin{array}{c}\text { chi-kwadraat toets } \\
\text { op verschil }\end{array}$ \\
\hline $\begin{array}{l}\text { Vakkennis } \\
\text { Vakspecifieke methoden en }\end{array}$ & 28 & 26 & 0,6 \\
technieken & 25 & 31 & $4,7^{*}$ \\
$\begin{array}{l}\text { Recente ontwikkelingen in het } \\
\text { vakgebied }\end{array}$ & 68 & 56 & $14,8^{* *}$ \\
$\begin{array}{l}\text { Inzicht in informatie- \& } \\
\text { communicatietechnologie }\end{array}$ & 30 & 55 & $55,7^{\star *}$ \\
$\begin{array}{l}\text { Toepassen van (theoretische) } \\
\text { kennis en technieken in de praktijk }\end{array}$ & 34 & 35 & 0,2 \\
$\begin{array}{l}\text { Analytische en diagnostische } \\
\text { (onderzoeks)vaardigheden }\end{array}$ & 30 & 35 & 3,1 \\
$\begin{array}{l}\text { Kwantitatieve onderzoeks- } \\
\text { vaardigheden }\end{array}$ & 8 & 12 & $4,7^{*}$ \\
*=significant bij 5\%-niveau & & & \\
$* *$ significant bij 1\%-niveau & & & \\
\hline Bron: ROA (HBO-Monitor) & & &
\end{tabular}

Bron: ROA (HBO-Monitor)

Tabel 4.6 geeft een overzicht van het percentage recent afgestudeerde HBO'ers werkzaam in het informatica-beroependomein dat in hun opleiding meer aandacht had willen besteden aan bepaalde vaktechnische kennis en vaardigheden. Aangezien degenen zonder informatica-opleiding minder vaak in informatica-beroepen werken waarvoor vakkennis vereist is ondervinden ze ook niet zoveel knelpunten op dit gebied. Hetzelfde geldt voor het toepassen van kennis en technieken in de praktijk. Voor beide aspecten is er tussen werkenden met een informatica-opleiding en werkenden zonder informatica-opleiding geen significant verschil in het percentage dat er meer aandacht aan had willen besteden. Wel willen werkenden in het informatica-domein die geen informatica-opleiding hebben gevolgd vaker meer aandacht voor vakspecifieke methoden en technieken, informatie- en communicatietechnologie en kwantitatieve onderzoeksvaardigheden. Vooral bij het aspect inzicht in informatie en communicatietechnologie is het verschil groot. Blijkbaar worden op dit gebied veel knelpunten ondervonden door werkenden zonder opleiding in de informatica. Dat personen zonder informatica-opleiding vaker meer aandacht voor kwantitatieve onderzoeksvaardigheden vragen is overigens niet zo verwonderlijk daar zij ook vaker werkzaam zijn in functies waar deze vaardigheden van belang zijn. Opvallend is verder dat HBO'ers die wel een informatica-opleiding hebben gevolgd vaker meer aandacht hadden gewild voor recente ontwikkelingen in hun vakgebied. Mogelijk is dit te verklaren uit het feit dat vakkennis voor deze groep van groter belang is. 
Geconcludeerd kan worden dat HBO'ers die werkzaam zijn in het informatica-domein maar geen informatica-opleiding hebben afgerond vaker knelpunten ondervinden op het gebied van vaktechnische kennis en vaardigheden dan HBO'ers die wel een informatica-opleiding hebben gevolgd. Toch zijn de verschillen minder groot dan verwacht, omdat HBO'ers die geen informatica-opleidingsachtergrond hebben, binnen het informatica-domein vaker in functies terecht komen waar vakspecifieke kennis en vaardigheden wat minder belangrijk zijn.

Gegevens van de Intermediair loopbaanenquête onder werkenden met een HBO- of WO-opleiding suggereren eveneens dat mensen met een informatica-opleidingsachtergrond vaker werkzaam zijn in de meer complexere informatica-beroepen. Degenen die werkzaam zijn in de informatisering en ook een informatica-opleidingsachtergrond hebben, geven namelijk iets vaker aan dat hun werkgever veel geld en aandacht heeft besteed aan de ontwikkeling van inhoudelijke en vaktechnische kennis en vaardigheden terwijs ze tegelijkertijd ook vaker meer aandacht voor dit aspect vragen.

\section{Cursussen}

Knelpunten die ontstaan door een slechte aansluiting tussen opleiding en beroep kunnen worden verholpen door het volgen van aanvullende opleidingen. Daarom zal nu bekeken worden of de slechtere aansluiting tussen opleiding en beroep voor HBO'ers die werkzaam zijn in het informatica-domein maar geen informatica-opleiding hebben gevolgd er toe leidt dat deze vaker aanvullende training krijgen.

Tabel 4.7

Percentage recent afgestudeerde HBO'ers werkzaam in het informatica-domein dat behoefte heeft aan bijscholing, 1996

*=significant bij $5 \%$-niveau

${ }^{* *}=$ significant bij $1 \%$-niveau

Bron: ROA (HBO-Monitor)

Meer in het algemeen is er een grote behoefte aan bijscholing, zoals blijkt uit tabel 4.7 Meer dan de helft van alle recent afgestudeerde HBO'ers werkzaam in het informaticadomein geeft aan behoefte aan bijscholing te hebben. Opvallend genoeg verschilt het percentage dat behoefte heeft aan bijscholing nauwelijks tussen afgestudeerden van een informatica-opleiding en afgestudeerden van overige HBO-opleidingen. 
Tabel 4.8

Percentage recent afgestudeerde HBO'ers werkzaam in het informatica-domein dat na afstuderen één of meerdere cursussen heeft gevolgd, 1996

\begin{tabular}{lccl}
\hline & $\begin{array}{c}\text { HBO informatica } \\
\%\end{array}$ & $\begin{array}{c}\mathrm{HBO} \text { overig } \\
\%\end{array}$ & $\begin{array}{l}\text { chi-kwadraat toets } \\
\text { op verschil }\end{array}$ \\
\hline Alle cursussen & 70 & 58 & $15,8^{\star *}$ \\
Informatica-cursussen & 21 & 37 & $19,9^{\star *}$ \\
$* *$ significant bij 1\%-niveau & & & \\
\hline Bron: ROA (HBO-Monitor) & & &
\end{tabular}

Niet alleen hebben HBO'ers die geen informatica-opleiding hebben gevolgd nauwelijks vaker behoefte aan bijscholing, ze volgen ook minder vaak cursussen of bedrijfsopleidingen, zoals blijkt uit tabel 4.8 . Terwijl $70 \%$ van degenen die een opleiding $H B O$ informatica hebben afgerond zegt na hun afstuderen één of meerdere bedrijfsopleidingen of cursussen te hebben gevolgd, is dat percentage voor HBO'ers met een andere opleidingsachtergrond nog geen $60 \%$. Als echter alleen de opleidingen op het gebied van de informatica in beschouwing worden genomen, krijgen we een heel ander beeld. Bijna $40 \%$ van de recent afgestudeerden die een $\mathrm{HBO}$-opleiding buiten de informatica hebben gevolgd, heeft na hun afstuderen een cursus of bedrijfsopleiding op het gebied van de informatica gevolgd. Van degenen die wel een opleiding $H B O$ informatica hebben gevolgd is dat slechts $20 \%$. Een slechtere aansluiting tussen opleiding en beroep als gevolg van tekortschietende kennis en vaardigheden op het gebied van de informatica leidt dus wel degelijk tot meer training op het gebied van de informatica. Het lijkt hier te gaan om intrede-cursussen om de bestaande lacunes in de vereiste vaardigheden voor de functie die men uitoefent op te vullen. Aan de andere kant wijst de grote scholingsbehoefte onder afgestudeerden van informatica-opleidingen er op dat ook zij genoodzaakt zijn zich bij te scholen.

\section{Beloning in het informatica-domein}

In hoofdstuk $3 \mathrm{kwam}$ naar voren dat de recent afgestudeerden van HBO informatica gemiddeld meer verdienen dan HBO'ers van andere opleidingen. Deze hogere beloning kan voortkomen uit het feit dat functies in het informatica-domein gemiddeld beter betalen. In dat geval zou echter ook de beloning van recent afgestudeerden van andere opleidingen die werkzaam zijn in het informatica-domein hoger moeten zijn dan gemiddeld. We zullen daarom nu bekijken of recent afgestudeerden van informaticaopleidingen ook binnen het informatica-domein een voorsprong hebben. Als de kennis en vaardigheden van recent afgestudeerden van informatica-opleidingen namelijk inderdaad beter aansluiten bij de vereiste kennis en vaardigheden in het informaticadomein dan zal de beloning van deze afgestudeerden naar verwachting ook hoger zijn dan de beloning van recent afgestudeerden die geen informatica-opleiding hebben afgerond. 
Tabel 4.9

Schattingsresultaten van loonvergelijking voor recent afgestudeerde HBO'ers werkzaam in het informatica-domein, 1996

\begin{tabular}{lcc}
\hline & coëfficiënt & t-waarde \\
\hline Onderbenutting & $-0,03$ & $3,0^{* *}$ \\
Overbenutting & 0,04 & 1,4 \\
Informatica-beroep $p^{1)}$ & & \\
Programmeurs & $-0,04$ & $-1,1$ \\
Technisch systeemanalisten & 0,02 & 1,6 \\
Informatici & $-0,13$ & $-1,1$ \\
Informatica-opleiding & 0,04 & $3,4^{* *}$ \\
Deeltijdstudie & 0,23 & $5,4^{* *}$ \\
Leeftijd & 0,01 & 0,6 \\
Leeftijd $2 / 100$ & 0,00 & 0,1 \\
Vrouw & $-0,01$ & $-0,6$ \\
Allochtoon & $-0,40$ & $-1,1$ \\
Constante & 2,60 & $7,7^{* *}$ \\
$\mathrm{R}^{2}=0,19$ & & \\
$\mathrm{~F}(11,933)=21,5^{* *}$ & & \\
1) $=$ referentie zijn Systeemanalisten & & \\
$*=$ significant op 5\%-niveau & & \\
$*$ ** significant op 1\%-niveau & & \\
\hline Bron: ROA (HBO-Monitor) & &
\end{tabular}

Tabel 4.9 geeft de resultaten van een analyse van de factoren die van invloed zijn op het bruto uurloon van recent afgestudeerde HBO'ers werkzaam in het informaticadomein ${ }^{8}$. Het bruto uurloon wordt verklaard uit het niveau van het beroep. Daarbij is met name gekeken of sprake is van onderbenutting of overbenutting. Van onderbenutting is sprake als het niveau van het beroep lager is dan het HBO-niveau en van overbenutting als het niveau hoger is dan HBO-niveau. Daarnaast wordt het bruto uurloon verklaard op basis van de beroepsgroep binnen het informatica-domein, de opleidingsachtergrond van de schoolverlater (of er al dan niet een informatica-opleiding is afgerond), of iemand in deeltijd heeft gestudeerd, leeftijd, geslacht en etniciteit. Het blijkt dat ook als gecorrigeerd wordt voor beroepskenmerken en persoonskenmerken recent afgestudeerden van informatica-opleidingen gemiddeld $4 \%$ meer verdienen dan recent afgestudeerden van andere opleidingen. Dit resultaat wijst er opnieuw op dat kennis en vaardigheden van recent afgestudeerden van informatica-opleidingen bewerkstelligen dat men wordt ingezet in kennis-intensievere functies, dan de recent afgestudeerden met een andere opleidingsachtergrond, wat ook leidt tot een hogere productiviteit. Aansluitingsproblemen die recent afgestudeerden van andere opleidingen in dit domein ondervinden leiden ook tot een lager loon. Werk onder HBO-niveau leidt

8. Daarbij is uitgegaan van het natuurlijke logaritme van het bruto-uurloon. 
ook in het informatica-domein tot een inkomensverlies, terwijl werk op een hoger niveau niet tot een significante inkomenstoename leidt. De inkomensverschillen tussen de diverse beroepsgroepen in het informatica-domein zijn niet significant.

Geconcludeerd kan worden dat recent afgestudeerde HBO'ers die werkzaam zijn in het informatica-domein maar geen informatica-opleiding hebben gevolgd, vaker aansluitingsproblemen ondervinden door tekortschietende kennis- en vaardigheden. Deze aansluitingsproblemen leiden er toe dat deze groep vaker cursussen of bedrijfstrainingen volgt op het gebied van de informatica. Wel geldt dat recent afgestudeerde HBO'ers zonder informatica-opleiding vaker in functies werken binnen het informatica-domein waar vakspecifieke kennis en vaardigheden wat minder van belang zijn. Waarschijnlijk mede daardoor is de beloning van deze recent afgestudeerden ook lager dan die van degenen met een informatica-opleidingsachtergrond. 


\section{Toekomstige ontwikkelingen op de arbeidsmarkt voor informatici, 1997-2002}

\subsection{Inleiding}

In dit hoofdstuk zal een beeld worden geschetst van de verwachte ontwikkelingen op de arbeidsmarkt voor informatici voor de periode 1997-2002. We zullen daarbij gebruik maken van de arbeidsmarktprognoses uit het Project Onderwijs-Arbeidsmarkt (zie ook ROA, 1997 a, b). Figuur 5.1 geeft een schematisch overzicht van het gehanteerde prognosemodel. Aan de vraagzijde onderscheiden we de uitbreidingsvraag en de vervangingsvraag. De uitbreidingsvraag geeft de verwachte werkgelegenheidsontwikkeling in een beroepsgroep of opleidingstype. Uitgangspunt voor de uitbreidingsvraagprognoses vormen de bedrijfssectorprognoses van het Centraal Planbureau (CPB, 1996). De verwachte uitbreidingsvraag per bedrijfssector wordt vertaald in een uitbreidingsvraag per beroepsgroep. Daarbij wordt niet alleen rekening gehouden met werkgelegenheidsverschuivingen tussen bedrijfssectoren maar ook met werkgelegenheidsverschuivingen binnen bedrijfssectoren. In het laatste geval gaat het om veranderingen in de beroepenstructuur van een bedrijfssector. De vraag per beroepsgroep kan soms alleen worden vervuld door mensen met een specifieke opleidingsachtergrond, maar vaak ook door mensen met een sterk uiteenlopende opleidingsachtergrond. Door technologische veranderingen en toenemende complexiteit van veel beroepen treden er bovendien verschuivingen op in de vraag naar verschillende opleidingstypes vanuit een bepaalde beroepsgroep. Door rekening te houden met deze verschuivingen in de opleidingsstructuur van een beroepsgroep, kan de vraag per beroepsgroep vervolgens worden vertaald in een vraag per opleidingstype.

Zoals gezegd is er op de arbeidsmarkt naast uitbreidingsvraag ook sprake vervangingsvraag. Veel werknemers verlaten de arbeidsmarkt vanwege bijvoorbeeld pensionering, arbeidsongeschiktheid of tijdelijke terugtrekking van de arbeidsmarkt. Daarnaast is er ook sprake van beroepsmobiliteit, men blijft wel actief op de arbeidsmarkt maar wisselt van beroep. Als het vertrek van een werknemer ook daadwerkelijk tot een vacature leidt is er sprake van vervangingsvraag.

De uitbreidingsvraag en de vervangingsvraag vormen tezamen de totale vraag naar nieuwkomers op de arbeidsmarkt. Tegenover deze verwachte vraag naar nieuwkomers staat het verwachte aanbod van nieuwkomers. Het aanbod bestaat uit de toekomstige arbeidsmarktinstroom van schoolverlaters en de doorstroom naar niet-reguliere vervolgopleidingen in de prognoseperiode en het aantal kortdurige werklozen aan het begin van deze periode. Verondersteld is dat alleen personen die korter dan een jaar werkloos zijn serieuze concurrenten kunnen zijn voor schoolverlaters. 
Figuur 5.1

Globale opzet van prognosemodel

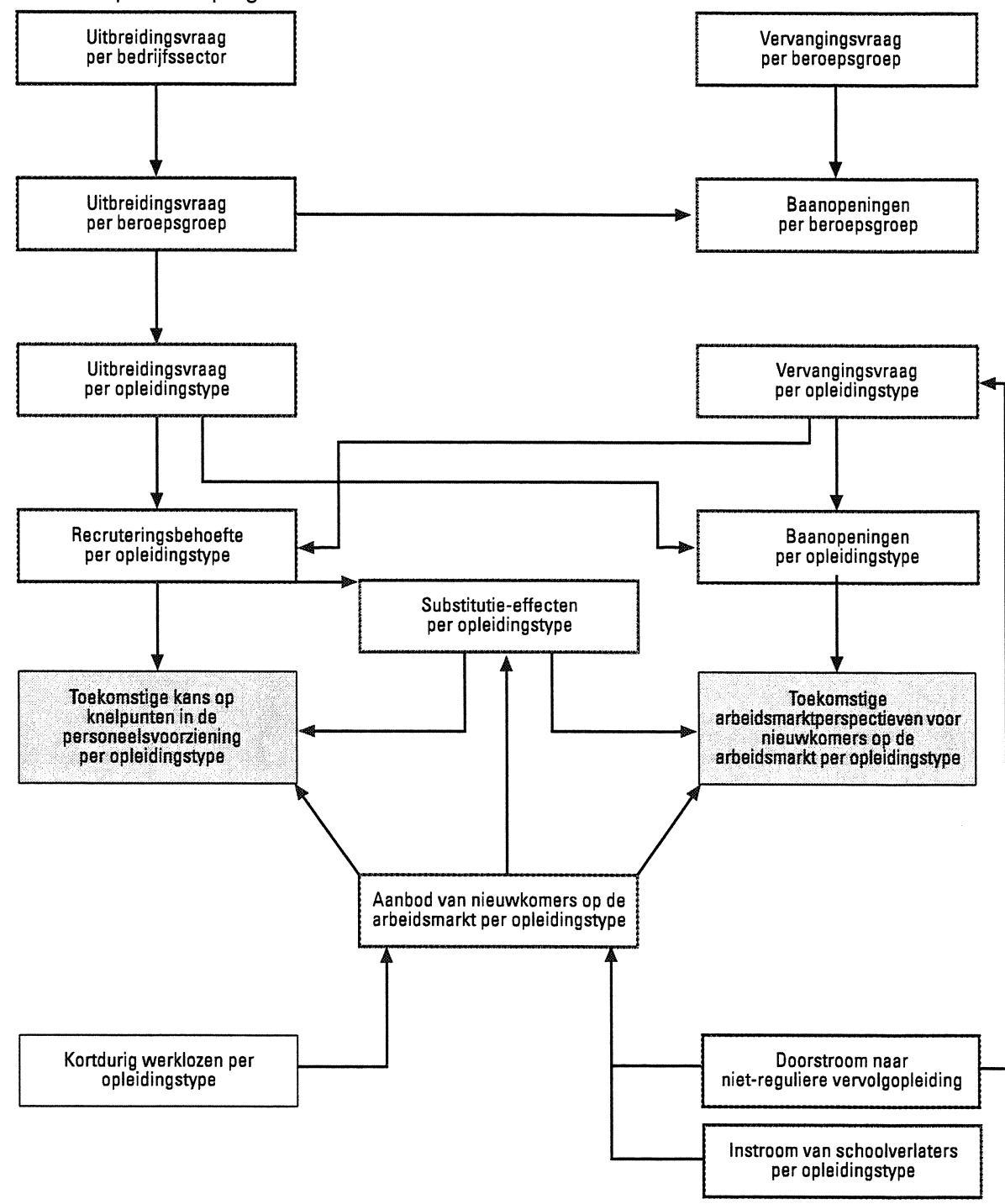

Door de verwachte vraag- en aanbodstromen per opleidingstype te confronteren wordt een beeld gekregen van de toekomstige knelpunten in de personeelsvoorziening (ITKP) die werkgevers zullen ondervinden. Discrepanties tussen vraag en aanbod per opleidingstype leiden overigens niet per definitie tot werkloosheid of openstaande vacatures. Bij een tekortschietend aanbod van een bepaald opleidingstype kunnen werkgevers er toe overgaan om schoolverlaters van andere opleidingen te rekruteren, zoals in het verleden ook is gebeurd bij verschillende informaticafuncties. Ook als werkgevers er op deze wijze in slagen vacatures op te vullen, is er toch sprake van 
knelpunten in de personeelsvoorziening omdat werkgevers meer inspanningen moeten verrichten om mensen te vinden en mogelijk ook betere arbeidscondities zullen moeten gaan aanbieden.

Uit het bovenstaande wordt tevens duidelijk dat een aanbodoverschot of -tekort bij het ene opleidingstype ook gevolgen heeft voor andere opleidingstypes. Bij een aanbodtekort bij een opleidingstype neemt de vraag bij andere opleidingstypes toe terwijl bij een aanbodoverschot andere opleidingstypes juist verdrongen worden. Bij het bepalen van de ITKP wordt ook rekening gehouden met de toe- of afname van de vraag als gevolg van tekorten of overschotten bij andere opleidingstypes.

In de volgende paragrafen zullen we ingaan op de vraag- en aanbodprognoses voor informatici. In paragraaf 5.2 worden eerst de verwachte arbeidsmarktontwikkelingen in het informatica-domein besproken. Daarbij wordt niet alleen een beeld geschetst van de verwachte ontwikkelingen aan de vraagzijde van de arbeidsmarkt maar zal ook worden ingegaan op de knelpunten die zullen optreden bij het vervullen van deze vraag. Vervolgens zal in paragraaf 5.3 worden ingegaan op de verwachte vraag- en aanbodontwikkelingen en de daaruit voortvloeiende discrepanties voor de informaticaopleidingen.

\subsection{Verwachte werkgelegenheidsontwikkelingen en knelpunten bij informatica- beroepen}

In hoofdstuk 2 bleek dat de werkgelegenheid in het informatica-domein, na enige jaren vrij stabiel te zijn geweest, vanaf 1995 weer is gegroeid. Deze groei zal zich naar verwachting de komende jaren voortzetten. Tabel 5.1 geeft een overzicht van de verwachte uitbreidingsvraag in het informatica-domein voor de periode 1997-2002. Met uitzondering van de beroepsgroep Elektrotechnici, waar de werkgelegenheid iets zal dalen, zal de werkgelegenheid in alle beroepsgroepen die tot het informatica-domein worden gerekend groeien. De totale groei in het informatica-domein is ongeveer $18 \%$, wat neerkomt op ruim 3\% per jaar. Daarmee ligt de werkgelegenheidsgroei in het informatica-domein beduidend hoger dan de totale werkgelegenheidsgroei, die 1,7\% per jaar bedraagt. De werkgelegenheidsgroei is zowel absoluut als relatief gezien het grootst in de beroepsgroep Systeemanalisten. Ook voor Programmeurs en Informatici is de uitbreidingsvraag relatief hoog. De uitbreidingsvraag voor Technisch systeemanalisten is gemiddeld.

Tabel 5.2 laat zien dat de vervangingsvraag vanuit het informatica-domein over het algemeen wat lager is dan gemiddeld. Deze lagere vervangingsvraag is deels te verklaren uit de relatief jonge leeftijd van de werkenden in het informatica-domein. Daarnaast is ook het aandeel van vrouwen in dit beroependomein aan de lage kant. Aangezien vrouwen zich nog altijd vaker (tijdelijk) terugtrekken van de arbeidsmarkt zal in beroepen waar het percentage vrouwen laag is, de vervangingsvraag wat lager zijn 
dan gemiddeld.

Tabel 5.1

Verwachte uitbreidingsvraag per beroepsgroep in het informatica-domein, 1997-2002

\begin{tabular}{|c|c|c|c|c|}
\hline Beroepsgroep & aantal & $\begin{array}{l}\text { totaal } \\
\%\end{array}$ & $\begin{array}{l}\text { gemiddeld } \\
\text { jaarlijks } \%\end{array}$ & typering \\
\hline $\begin{array}{l}\text { Programmeurs } \\
\text { Technisch systeemanalisten } \\
\text { Systeemanalisten } \\
\text { Elektrotechnici } \\
\text { Informatici }\end{array}$ & $\begin{array}{r}8.800 \\
1.100 \\
19.000 \\
-200 \\
2.900\end{array}$ & $\begin{array}{l}16 \\
10 \\
22 \\
-2 \\
19\end{array}$ & $\begin{array}{r}3,0 \\
2,0 \\
4,0 \\
-0,5 \\
3,6\end{array}$ & $\begin{array}{l}\text { hoog } \\
\text { gemiddeld } \\
\text { hoog } \\
\text { laag } \\
\text { hoog }\end{array}$ \\
\hline
\end{tabular}

Bron: ROA

Tabel 5.2

Verwachte vervangingsvraag per beroepsgroep in het informatica-domein, 1997-2002

\begin{tabular}{lrrrl}
\hline Beroepsgroep & aantal & $\begin{array}{c}\text { totaal } \\
\%\end{array}$ & $\begin{array}{l}\text { gemiddeld typering } \\
\text { jaarlijks \% }\end{array}$ \\
\hline Programmeurs & 4.800 & 9 & 1,7 & erg laag \\
Technisch systeemanalisten & 1.800 & 17 & 3,2 & gemiddeld \\
$\begin{array}{l}\text { Systeemanalisten } \\
\text { Elektrotechnici }\end{array}$ & 11.000 & 13 & 2,4 & laag \\
Informatici & 1.000 & 13 & 2,5 & laag \\
& 1.600 & 11 & 2,0 & erg laag \\
\hline
\end{tabular}

Bron: ROA

De uitbreidingsvraag en de vervangingsvraag geven tezamen de rekruteringsbehoefte in het informatica-domein. De rekruteringsbehoefte is laag voor de beroepsgroep Elektrotechnici, gemiddeld voor Programmeurs, Technisch systeemanalisten en Informatici en hoog voor Systeemanalisten. Dus hoewel de uitbreidingsvraag bij de meeste beroepsgroepen in het informatica-domein vrij hoog is leidt de wat lagere vervangingsvraag er toe dat de totale rekruteringsbehoefte voor nieuwkomers in de meeste informatica-beroepen toch niet bijzonder hoog is. De uitzondering is echter de grootste beroepsgroep - de Systeemanalisten - waar de totale rekruteringsbehoefte groot is.

Tabel 5.3

Verwachte rekruteringsbehoefte per beroepsgroep in het informatica-domein, 1997-2002

\begin{tabular}{lrrrl}
\hline Beroepsgroep & aantal & $\begin{array}{r}\text { totaal } \\
\%\end{array}$ & $\begin{array}{r}\text { gemiddeld } \\
\text { jaarlijks \% }\end{array}$ & typering \\
\hline Programmeurs & 13.600 & 25 & 4,7 & gemiddeld \\
Technisch systeemanalisten & 2.900 & 27 & 5,2 & gemiddeld \\
Systeemanalisten & 30.000 & 34 & 6,4 & hoog \\
Elektrotechnici & 800 & 10 & 2,0 & laag \\
Informatici & 4.500 & 30 & 5,6 & gemiddeld \\
\hline
\end{tabular}

Bron: ROA 
Het is ook interessant om na te gaan in welke mate werkgevers knelpunten zullen gaan ondervinden bij het vervullen van deze baanopeningen. Met het oog daarop is de Indicator toekomstige knelpunten in de personeelsvoorziening per beroepsgroep (ITKB) opgesteld, die het aanbod per beroep vergelijkt met de vraag per beroep (zie ook Appendix 2). Tabel 5.4 geeft een overzicht van de toekomstige knelpunten in de personeelsvoorziening in het informatica-domein. Naarmate de ITKB lager is, is de discrepantie tussen de vraag en het aanbod per beroepsgroep groter en zijn er meer knelpunten in de personeelsvoorziening te verwachten.

Tabel 5.4

Indicator toekomstige knelpunten in de personeelsvoorziening in het informatica-domein naar beroepsgroep

\begin{tabular}{lll}
\hline Beroepsgroep & ITKB & $\begin{array}{l}\text { typering } \\
\text { knelpunten }\end{array}$ \\
\hline Programmeurs & 0,94 & vrijwel geen \\
Technisch systeemanalisten & 0,90 & groot \\
Systeemanalisten & 0,90 & groot \\
Elektrotechnici & 0,89 & groot \\
Informatici & 0,88 & zeer groot \\
\hline
\end{tabular}

Bron: ROA

Ondanks de hoge groei van de werkgelegenheid in de beroepsgroep Programmeurs zullen werkgevers vrijwel geen knelpunten ondervinden bij het werven van nieuwe werknemers in deze beroepsgroep. Blijkbaar groeit het aanbod voor deze beroepsgroep in dezelfde mate als de vraag. Voor de overige beroepsgroepen in het informaticadomein is de kans op knelpunten in de personeelvoorziening groot tot zeer groot. Dat geldt ook voor de beroepsgroep Elektrotechnici. Ondanks een afname van de werkgelegenheid schiet het aanbod voor deze beroepsgroep dusdanig tekort dat werkgevers toch problemen zullen ondervinden bij het rekruteren van nieuw personeel. In hoofdstuk 3 bleek dat de informatica-beroepen vooral van belang zijn voor de zakelijke dienstverlening, communicatie, het bank- en verzekeringswezen en de metaalen elektrotechniek. In deze bedrijfssectoren zullen daarom ook de meeste knelpunten worden ondervonden als gevolg van een tekortschietend aanbod voor het informaticadomein. In de metaal- en elektrotechniek zullen dan met name knelpunten worden ondervonden bij het vervullen van de vraag vanuit de beroepsgroepen Systeemanalisten en Elektrotechnici, terwijl in de dienstverlenende sectoren daarnaast ook veel problemen zullen ontstaan in de beroepsgroepen Informatici en Technisch systeemanalisten. De tekorten op de arbeidsmarkt voor informatici blijken dus structureel te zijn. Om meer inzicht te krijgen in de oorzaken van de tekorten zal in de volgende paragraaf worden ingegaan op vraag- en aanbodontwikkelingen voor de informatica-opleidingen.

\subsection{Verwachte knelpunten bij informatica-opleidingen}

De vraag naar hoger opgeleide informatici zal de komende jaren sterk toenemen, zoals 
blijkt uit tabel 5.5. Voor HBO informatica is de verwachte uitbreidingsvraag hoog en voor WO informatica en bestuurlijke informatiekunde zelfs erg hoog. De verwachte uitbreidingsvraag naar personen met een automatiseringsopleiding op middelbaar niveau is echter veel geringer.

Tabel 5.6 gaat in op de componenten van de verwachte uitbreidingsvraag voor de verschillende informatica-opleidingen. Daarbij wordt een onderscheid gemaakt tussen een aantal vraageffecten. Het bedrijfsectoreffect geeft de verwachte uitbreidingsvraag als gevolg van de werkgelegenheidgroei per bedrijfssector. Het beroepseffect heeft betrekking op de vraagtoename als gevolg van de verschuiving van het werkgelegenheidsaandeel van de beroepen waarin informatici werkzaam zijn binnen de betreffende bedrijfssectoren. Het opleidingseffect geeft vervolgens de extra vraag als gevolg van verschuivingen in de vraag naar mensen met een informatica-opleiding binnen de informatica-beroepen.

Tabel 5.5

Verwachte uitbreidingsvraag per opleidingstype, 1997-2002

\begin{tabular}{lrrrl}
\hline Opleidingstype & aantal & $\begin{array}{r}\text { totaal } \\
\%\end{array}$ & $\begin{array}{r}\text { gemiddeld } \\
\text { jaarlijks \% }\end{array}$ & typering \\
\hline MBO/LLW automatisering & 5.100 & 13 & 2,5 & gemiddeld \\
HBO informatica & 10.200 & 28 & 5,0 & hoog \\
WO informatica en bestuurlijke & 4.700 & 60 & 9,8 & erg hoog \\
informatiekunde & & & & \\
\hline Bron: ROA & & & &
\end{tabular}

Tabel 5.6

De uitbreidingsvraag voor informatica-opleidingen opgesplitst naar onderliggende vraag-effecten, 1997-2002

\begin{tabular}{lllll}
\hline & $\begin{array}{l}\text { bedrijfssector- } \\
\text { effect } \\
\%\end{array}$ & $\begin{array}{l}\text { beroeps- } \\
\text { effect } \\
\%\end{array}$ & $\begin{array}{l}\text { opleidings- } \\
\text { effect } \\
\%\end{array}$ & $\begin{array}{l}\text { totaal } \\
\%\end{array}$ \\
\hline Opleidingstype & 11 & 4 & -2 & 13 \\
$\begin{array}{l}\text { MBO/LLW automatisering } \\
\text { WO informatica }\end{array}$ & 12 & 4 & 12 & 28 \\
informatiekunde & 13 & 4 & 43 & 60 \\
\hline Bron: ROA & & & &
\end{tabular}

Bron: ROA

De tabel laat zien dat het bedrijfssectoreffect iets oploopt met het opleidingsniveau, hoewel de verschillen op dit punt vrij gering zijn. Het beroepseffect is voor alle opleidingsniveaus $4 \%$. Dit betekent dat het belang van beroepen waarin mensen met een opleiding WO informatica en bestuurlijke informatiekunde en HBO informatica werkzaam zijn niet meer toeneemt dan het belang van beroepen waarin degenen met de opleiding MBO/LLW automatisering werkzaam zijn. Het grote verschil in de 
uitbreidingsvraag tussen de verschillende opleidingsniveaus blijkt te worden veroorzaakt door het opleidingseffect. Bij MBO/LLW automatisening is het opleidingseffect opmerkelijk genoeg negatief. Dit betekent dat het werkgelegenheidsaandeel van degenen met deze opleidingsachtergrond binnen de beroepsgroepen waarin men werkzaam is zal gaan afnemen. Bij HBO informatica en WO informatica en bestuurlijke informatiekunde zal het belang binnen de diverse beroepsgroepen daarentegen gaan toenemen. Met name bij WO informatica en bestuurlijke informatiekunde is het opleidingseffect enorm. Dit wijst er op dat informatica-beroepen steeds complexer worden waardoor informaticakwalificaties in deze beroepen steeds belangrijker worden. In hoofdstuk 3 zagen we dat ook in de periode 1992-1996 het werkgelegenheidsaandeel van WO informatica en bestuurlijke informatica sterk toenam. Deze ontwikkeling zal zich dus naar verwachting de komende jaren voortzetten. In hoeverre werkgevers er daadwerkelijk in zullen slagen om meer hoger opgeleide informatici aan te stellen, zal echter afhankelijk zijn van het toekomstige aanbod aan hoger opgeleide informatici.

Tabel 5.7

Verwachte vervangingsvraag per opleidingstype, 1997-2002

\begin{tabular}{lcccc}
\hline Opleidingstype & aantal & $\begin{array}{l}\text { totaal } \\
\%\end{array}$ & $\begin{array}{l}\text { gemiddeld } \\
\text { jaarlijks \% }\end{array}$ & typering \\
\hline MBO/LLW automatisering & 4.000 & 10 & 2,0 & erg laag \\
$\begin{array}{l}\text { HBO informatica } \\
\text { WO informatica en bestuurlijke }\end{array}$ & 5.100 & 14 & 2,6 & laag \\
informatiekunde & 800 & 10 & 1,8 & erg laag \\
\hline Bron: ROA & & & &
\end{tabular}

Tabel 5.8

Verwachte rekruteringsbehoefte per opleidingstype, 1997-2002

\begin{tabular}{lrlll}
\hline Opleidingstype & aantal & $\begin{array}{l}\text { totaal } \\
\%\end{array}$ & $\begin{array}{l}\text { gemiddeld } \\
\text { jaarlijks \% }\end{array}$ & typering \\
\hline $\begin{array}{l}\text { MBO/LLW automatisering } \\
\text { HBO informatica }\end{array}$ & 9.100 & 24 & 4,5 & gemiddeld \\
$\begin{array}{l}\text { WO informatica en bestuurlijke } \\
\text { informatiekunde }\end{array}$ & 15.300 & 41 & 7,6 & gemiddeld \\
\hline Bron: ROA & 5.500 & 69 & 11,6 & erg hoog \\
\hline
\end{tabular}

\section{Bron: ROA}

De vervangingsvraag is voor de informatica-opleidingen laag tot erg laag. Deze lage vervangingsvraag wordt, evenals de lage vervangingsvraag vanuit het informaticaberoepsdomein, voornamelijk verklaard door de jonge leeftijd van de werkenden met een informatica-opleiding. $\mathrm{Bij} M B O / L L W$ automatisering valt bijvoorbeeld slechts $8 \%$ van de werkenden in de leeftijdscategorie 50 tot en met 64 jaar, terwijl van de totale werkzame beroepsbevolking $15 \%$ in deze leeftijdscategorie valt. Bij WO informatica en bestuurlijke informatiekunde is zelfs meer dan de helft van de werkenden jonger dan 30 jaar. 
Ondanks deze erg lage vervangingsvraag blijt de totale rekruteringsbehoefte voor WO informatica en bestuurlijke informatiekunde erg hoog. Voor HBO informatica en MBO automatisering kan de totale rekruteringsbehoefte in de periode 1997-2002 als gemiddeld worden getypeerd.

Tabel 5.9

Verwachte instroom van schoolverlaters per opleidingstype, 1997-2002

\begin{tabular}{lccll}
\hline Opleidingstype & aantal & $\begin{array}{l}\text { totaal } \\
\%\end{array}$ & $\begin{array}{l}\text { gemiddeld } \\
\text { jaarlijks \% }\end{array}$ & typering \\
\hline $\begin{array}{l}\text { MBO/LLW automatisering } \\
\text { HBO informatica }\end{array}$ & 7.400 & - & - & - \\
$\begin{array}{l}\text { WO informatica en bestuurlijke } \\
\text { informatiekunde }\end{array}$ & 3.000 & 38 & 6,6 & gemiddeld \\
\hline
\end{tabular}

Bron: ROA

Tabel 5.9 geeft een beeld van de verwachte arbeidsmarktinstroom van schoolverlaters voor de onderscheiden informatica-opleidingen. Omdat vrijwel alle automatiseringsopleidingen op middelbaar niveau niet regulier zijn, is het niet goed mogelijk om betrouwbare arbeidsmarktinstroomprognoses voor het opleidingstype MBO/LLW automatisering op te stellen. De verwachte arbeidsmarktinstroom voor HBO informatica is in verhouding tot het totaal aantal werkenden met deze opleidingsachtergrond gemiddeld te noemen. Voor WO informatica en bestuurlijke informatiekunde is de verwachte arbeidsmarktinstroom van afgestudeerden de komende jaren zelfs hoog. Toch zal het aanbod van nieuwkomers op de arbeidsmarkt ook bij dit opleidingstype de komende jaren tekortschieten. Dit blijkt duidelijk uit tabel 5.10, waarin de Indicator voor de Knelpunten in de Personeelsvoorziening (ITKP) wordt gepresenteerd.

De meeste knelpunten in de personeelsvoorziening worden verwacht bij WO informatica en bestuunlijke informatiekunde. Ondanks het feit dat bij WO informatica en bestuurlijke informatiekunde sprake is van een hoge arbeidsmarktinstroom van afgestudeerden, is deze instroom toch te laag om tegemoet te komen aan de vraag naar informatici op WO-niveau. Ook bij HBO informatica is de vraag, hoewel deze wat lager is dan bij WO informatica en bestuurlijke informatica, toch nog zo hoog in verhouding tot het aanbod dat ook bij dit opleidingstype de kans op knelpunten in de personeelsvoorziening zeer groot is.

In de vorige paragraaf bleek reeds dat er bij de meeste beroepsgroepen die tot het informatica-domein worden gerekend knelpunten in de personeelsvoorziening worden verwacht. We zullen nu bekijken in hoeverre deze knelpunten worden veroorzaakt door tekorten aan mensen met een bepaalde informatica-opleiding. Tabel 5.11 geeft per beroepsgroep het aandeel van het tekort dat wordt veroorzaakt door tekorten bij respectievelijk de opleidingen $M B O / L L W$ automatisering, $H B O$ informatica, en WO informatica en bestuurlijke informatiekunde. De tabel laat zien dat een derde van de 
tekorten in de beroepsgroep Programmeurs worden veroorzaakt door tekorten aan arbeidskrachten met een opleiding MBO/LLW automatisering. In deze beroepsgroep worden nauwelijks knelpunten ondervonden als gevolg van een tekort aan hoger opgeleide informatici. Bovendien bleek in paragraaf 5.2 al dat er sowieso weinig knelpunten in deze beroepsgroep worden verwacht.

Tabel 5.10

Indicator toekomstige kans op knelpunten in de personeelsvoorziening (ITKP) naar opleidingstype in 2002

\begin{tabular}{lll}
\hline Opleidingstype & ITKP & typering knelpunten \\
\hline MBO/LLW automatisering & & - \\
HBO informatica & - & - \\
WO informatica en bestuurlijke informatiekunde & 0,85 & zeer groot \\
& & zeer groot \\
\hline
\end{tabular}

Bron: ROA

De grote knelpunten in de personeelsvoorziening die verwacht worden voor de beroepsgroep Technisch systeemanalisten worden voor een groot deel veroorzaakt door tekorten aan afgestudeerden met een opleiding HBO informatica. Ook bij de Systeemanalisten wordt een deel van het tekort veroorzaakt door tekorten bij $H B O$ informatica. Daarnaast wordt in deze beroepsgroep ook veel hinder ondervonden van de tekorten aan afgestudeerde informatici op WO-niveau. Ten slotte worden in de beroepsgroepen Elektrotechnici en Informatici een belangrijk deel van de tekorten veroorzaakt door een tekort aan mensen met een opleiding WO informatica en bestuurlijke informatiekunde.

Overigens wordt ook een aanzienlijk deel van de knelpunten in de personeelsvoorziening veroorzaakt door tekorten bij andere opleidingen. Zo wordt $15 \%$ van de verwachte tekorten in de beroepsgroep Programmeurs veroorzaakt door tekorten bij MBO/LLW elektrotechniek. Tekorten bij HBO elektrotechniek zullen leiden tot knelpunten in de beroepsgroepen Technisch systeemanalisten en Elektrotechnici. In de beroepsgroep Elektrotechnici zullen zich ook knelpunten voordoen als gevolg van tekorten bij WO elektrotechniek. Verder zal in de beroepsgroep Informatici hinder worden ondervonden van tekorten aan mensen met een opleiding WO wiskunde en natuunwetenschappen en WO econome(tr)ie.

Ten slotte is het interessant om na te gaan hoe deze tekorten naar verwachting zullen worden opgevuld. Als er veel substitutiemogelijkheden tussen opleidingen zijn kan een werkgever immers tekorten aan afgestudeerden van een bepaald opleidingstype gemakkelijk opvangen door afgestudeerden uit andere opleidingsrichtingen aan te trekken. De substitutiemogelijkheden zijn vanzelfsprekend afhankelijk van de aard van de functie. In functies waar voornamelijk algemene vaardigheden van belang zijn, zijn er meer substitutiemogelijkheden dan in functies waar het accent ligt op zeer vakspecifieke vaardigheden. 
Tabel 5.11

Percentage van het tekort per beroepsgroep dat wordt veroorzaakt door tekorten aan personen met een informatica-opleiding, 2002

\begin{tabular}{lccc}
\hline & $\begin{array}{c}\text { MBO/LLW } \\
\text { automatisering }\end{array}$ & HBO informatica & $\begin{array}{l}\text { WO informatica en } \\
\text { bestuurlijke informatie- } \\
\text { kunde }\end{array}$ \\
\hline Programmeurs & $\%$ & $\%$ & $\%$ \\
Technisch systeemanalisten & 34 & 1 & 0 \\
Systeemanalisten & 2 & 36 & 1 \\
Elektrotechnici & 2 & 0 & 10 \\
Informatici & 0 & 7 & 34 \\
& 3 & & 25 \\
\hline
\end{tabular}

Bron: ROA

Ook als de substitutiemogelijkheden beperkt zijn kunnen werkgevers afgestudeerden van andere opleidingen werven. Vanwege een slechte aansluiting tussen opleiding en functie zullen werkgevers dan extra scholingskosten moeten maken. Naarmate werkgevers minder mogelijkheden hebben om tekorten van een bepaald opleidingstype op te vullen door afgestudeerden van andere opleidingen aan te trekken, zullen ze betere arbeidsvoorwaarden moeten aanbieden om toch mensen met de gewenste opleidingsachtergrond aan te trekken. Dat betekent dat in het geval van een tekort bij een bepaald opleidingstype, de werkgelegenheid van afgestudeerden zich waarschijnlijk zal gaan concentreren in beroepen waar de minste substitutiemogelijkheden zijn, dat wil zeggen waar de vakspecifieke vaardigheden van afgestudeerden het meest van belang zijn. In functies waar veel substitutiemogelijkheden zijn, is men doorgaans minder bereid om meer voor mensen met de aanvankelijk gewenste opleidingsachtergrond te gaan betalen dan in functies waar weinig substitutiemogelijkheden zijn.

Tabel 5.12

Belangrijkste opleidingstypen waarvan de werkgelegenheid in het informatica-domein toeneemt als gevolg aan tekorten bij andere opleidingen

\section{Programmeurs}

HAVONWO

Technisch systeemanalisten

Systeemanalisten

HAVONWO

Elektrotechnici

HBO elektrotechniek

HBO bedrijfskunde

WO werktuigbouwkunde

Informatici

WO sociale wetenschappen

Bron: ROA 
Tabel 5.12 geeft aan uit welke niet-informatica-opleidingsrichtingen werkgevers waarschijnlijk het eerst zullen gaan rekruteren, bij een tekortschietend aanbod. Daarbij is ook rekening gehouden met mogelijke tekorten bij deze andere opleidingsrichtingen. Dit laatste punt is vooral van belang omdat bij veel opleidingstypes die geschikt zouden zijn om tekorten aan hoger opgeleide informatici op te vullen ook sprake is van tekorten.

De in tabel 5.12 genoemde opleidingstypen zullen naar verwachting meer dan $5 \%$ van de werkgelegenheid in het beroep gaan uitmaken en meer dan $10 \%$ van de tekorten opvullen. In de beroepsgroepen Programmeurs en Systeemanalisten worden de tekorten vooral opgevuld door mensen te werven met een HAVO of WWO opleiding. Dit betekent dat er in deze beroepsgroepen veel aanvullende scholing zal moeten plaatsvinden om de nieuwkomers geschikt te maken voor hun functie. In de beroepsgroep Technisch systeemanalisten zijn, zoals bleek in hoofdstuk 4, de substitutiemogelijkheden beperkt. Buiten de opleidingstypes $H B O$ informatica en $H B O$ elektrotechniek zijn weinig opleidingen geschikt om vraag vanuit deze beroepsgroep te vervullen. Omdat bij beide opleidingstypen tekorten zullen optreden, zullen werkgevers veel inspanning moeten leveren om toch geschikte kandidaten te vinden. Tekorten in de beroepsgroep Elektrotechnici die behalve door een tekort aan opgeleiden in de richting WO informatica en bestuurijke informatiekunde ook worden veroorzaakt door tekorten aan opgeleiden uit de richting WO elektrotechniek, worden opgevuld door mensen aan te trekken met een opleiding HBO elektrotechniek, HBO bedrijfskunde en WO werktuigbouwkunde. Ten slotte zal voor de beroepsgroep Informatici met name aanvullend geworven gaan worden onder de afgestudeerden van het opleidingstype WO sociale wetenschappen. Ook hier zal dus een aanzienlijke scholingsinspanning geleverd moeten gaan worden. 


\section{Internationale vergelijking}

\subsection{Inleiding}

In dit hoofdstuk zal om de in dit rapport geschetste arbeidsmarkt voor informatici in Nederland enigszins in een internationaal perspectief te kunnen plaatsen, worden ingegaan op de resultaten van enkele studies naar de arbeidsmarkt voor informatici in Duitsland en Groot-Brittanië. In de Duitse studies ligt de nadruk op de ontwikkelingen in het aantal werkenden, de vacatures en de werkloosheid. Daarnaast wordt ook ingegaan op de opleidingsachtergrond van de werkenden (zie Baber e.a., 1992 en Dostal, 1995, 1996 en 1997). In een Engelse studie van Income Date Services (IDS, 1997) wordt met name ingegaan op de salarisontwikkelingen in het informatica-domein en de verwachte werkgelegenheidsgroei voor de komende jaren. Op grond van deze studies zal voor zover dat mogelijk is, een vergelijking worden gemaakt tussen de situatie op de Nederlandse arbeidsmarkt en de situatie in Duitsland en in GrootBrittannië. Eerst zal in paragraaf 6.2 de Duitse arbeidsmarkt voor informatici besproken worden. Daarna wordt in pragraaf 6.3 de Britse situatie toegelicht.

\subsection{De arbeidsmarkt voor informatici in Duitsland}

\section{De arbeidsmarkt voor informatici naar beroep}

In Duitsland is ongeveer $1 \%$ van alle werkenden werkzaam in een informatica-beroep. Zoals we in hoofdstuk 2 zagen, is het percentage werkenden dat werkzaam in een informatica-beroep voor Nederland bijna $2 \%$. Dit verschil moet echter met enige voorzichtigheid geïnterpreteerd worden. De beroepenclassificaties zijn immers niet geheel op elkaar afgestemd, waardoor de cijfers zoals die hier voor Duitsland gepresenteerd worden niet direct vergelijkbaar zijn met die van Nederland.

Ook in Duitsland is het aantal mensen dat werkzaam is in het informatica-domein de laatste jaren flink gestegen. In 1993 waren bijna 328 duizend personen werkzaam in informatica-beroepen (Dostal, 1996). In 1996 zijn naar schatting ongeveer 360 duizend mensen werkzaam in de informatica-beroepen. Dat is een stijging van ongeveer $10 \%$ in drie jaar tijd. Van die 360 duizend werkenden is ongeveer $20 \%$ werkzaam als zelfstandige of in een vrij beroep. Wel geldt dat in 1994 de werkgelegenheid in de informatica-beroepen wat daalde. De grootste groei heeft zich dus voorgedaan na 1994. Dit betekent dat de werkgelegenheidsontwikkelingen in de informatica-beroepen in Duitsland en Nederland dus min of meer parallel lopen.

Tabel 6.1 geeft een overzicht van het aantal werkenden in de verschillende informatica beroepsgroepen. Daarbij is een andere beroepenindeling gehanteerd dan bij de Nederlandse cijfers van het CBS. Deze tabel laat duidelijk zien dat in 1993 het grootste deel van de werkenden werkzaam is in de beroepsgroepen software-ontwikkelaars en 
programmeurs en datavenwerkings- en automatiseringspersoneel.

Tabel 6.1

Aantal werkenden in de informatica-beroepen in Duitsland, 1993

\begin{tabular}{lr}
\hline Beroepsgroep & Aantal \\
\hline Dataverwerkings- en automatiseringspersoneel & 97.000 \\
Software-ontwikkelaars en programmeurs & 113.400 \\
Automatiserings-organisatoren en systeemanalisten & 39.300 \\
Automatiserings-advies en verkooppersoneel & 25.200 \\
Help-desk en rekencentrum personeel & 35.900 \\
Ander automatiseringspersoneel & 16.900 \\
\hline Bron: Mikrozensus (MZ) & \\
\hline
\end{tabular}

Bron: Mikrozensus (MZ)

Omdat, zoals gezegd, de beroepenclassificaties niet op elkaar afgestemd zijn, zijn deze aandelen niet direct te vergelijken met de aandelen van de verschillende beroepsgroepen op de arbeidsmarkt in Nederland.

Het percentage vrouwen dat werkzaam is in een informatica-beroep ligt in Duitsland aanmerkelijk hoger dan in Nederland. Het percentage vrouwen dat actief is in het informatica-domein is in Nederland dan ook vrij laag. In de beroepsgroep Programmeurs is bijvoorbeeld slechts $13 \%$ van de werkenden vrouw en in de beroepsgroep Systeemanalisten $12 \%$. In Duitsland is het gemiddelde percentage vrouwen dat actief is in het informatica-domein $23 \%$. Opmerkelijk is verder dat het aandeel van vrouwen in het voormalig Oost-Duitsland met $41 \%$ veel hoger ligt dan de $21 \%$ in het westen. Verder laat tabel 6.2 zien dat in Duitsland in geen van de onderscheiden informaticaberoepen het percentage vrouwen onder de $16 \%$ ligt.

Tabel 6.2

Percentage vrouwen werkzaam in de informatica-beroepen in Duitsland, 1993

bron: Mikrozensus (MZ)

In de beschikbare Duitse studies wordt ook ingegaan op de ontwikkelingen in het aantal vacatures en werklozen. Als maatstaf voor de krapte op de arbeidsmarkt wordt het aantal werklozen dat zich aanbiedt voor informatica-beroepen gedeeld door het aantal vacatures in de informatica. Tabel 6.3 geeft een beeld van het totaal aantal werklozen en vacatures in het informatica-domein in september 1994 en 1995. In september 1994 
waren er nog 21 werklozen per informatica-vacature, maar in september 1995 was het aantal werklozen per vacature gedaald tot 12 . Dit komt zowel door een daling van het aantal werklozen dat als wensberoep een informatica-beroep heeft, als door een stijging van $56 \%$ van het aantal vacatures. Desalniettemin suggereert de vergelijking tussen de werkloosheids- en vacaturecijfers dat er in Duitsland de afgelopen jaren geen grote knelpunten zijn geweest in de personeelsvoorziening in het informatica-domein. Bekend is echter dat vacature-cijfers veel grote vertekeningen kennen (zie Muysken, 1994). Bovendien is het mogelijk dat de kwalificaties van werklozen die zich aanbieden voor informatica-beroepen onvoldoende aansluiten bij de vereiste kwalificaties.

Tabel 6.3

Werkloosheid en vacatures in informatica-beroepen in Duitsland, september 1995

\begin{tabular}{llll}
\hline & Werklozen & Vacatures & $\begin{array}{l}\text { Werklozen/ } \\
\text { vacatures }\end{array}$ \\
\hline 1994 & 30.183 & 1.452 & 21 \\
1995 & 26.458 & 2.271 & 12 \\
\hline
\end{tabular}

Bron: St 4 (Sondererhebung der BA über Arbeitslose Ende September)

Over heel 1995 werden er in totaal 24.000 vacatures geregistreerd voor informatici. In 1996 waren dit er al bijna 39.000. Dit is een stijging van 64\% ten opzichte van 1995. Ook in Nederland is het aantal vacatures in de automatiseringsbranche sterk gestegen vanaf 1996 (zie bijvoorbeeld Nibbering en Nitzsche, 1997).

Tabel 6.4

Werkloosheid en vacatures in informatica-beroepen in Duitsland, september 1995

\begin{tabular}{lccc}
\hline & Werklozen & Vacatures & $\begin{array}{l}\text { Werklozen/ } \\
\text { vacatures }\end{array}$ \\
\hline $\begin{array}{l}\text { Lager dataverwerkings/ } \\
\text { automatiseringspersoneel }\end{array}$ & 5.963 & 538 & 11 \\
$\begin{array}{l}\text { Automatiserings-organisator/ } \\
\text { systeemanalist }\end{array}$ & 1.845 & 113 & 16 \\
$\begin{array}{l}\text { Applicatieprogrammeur } \\
\text { Systeemprogrammeur }\end{array}$ & 4.663 & 431 & 11 \\
$\begin{array}{l}\text { Rekencentrumpersoneel } \\
\text { Automatiseringsverkooppersoneel }\end{array}$ & 6.080 & 65 & 10 \\
$\begin{array}{l}\text { Hoger dataverwerkings/ } \\
\text { automatiseringspersoneel }\end{array}$ & 1.763 & 117 & 26 \\
$\begin{array}{l}\text { Informatici* } \\
\text { Overig hoger automatiserings- }\end{array}$ & 4.194 & 167 & 11 \\
personeel & 3.367 & 122 & 34 \\
& 916 & 631 & 5 \\
\hline Bron: St4 (SOndererhebung & 87 & 11
\end{tabular}

Bron: St 4 (Sondererhebung der BA über Arbeitslose Ende September)

* Deze beroepsgroep is hier anders gedefineerd dan in de Nederlandse classificatie.

Tabel 6.4 geeft de werkloosheid en vacatures voor 1995 opgesplitst naar informatica- 
beroep ${ }^{9}$. De tabel laat zien dat ook voor hoger personeel dataverwerking en automatisering de arbeidsmarkt in 1995 erg ruim leek. Bij het rekencentrumpersoneel was de markt eveneens erg ruim.

De werkloosheid onder informatici is in $19968,1 \%$, in 1994 was dat nog 9,9\%, een indicatie dat de arbeidsmarkt voor informatici ook in Duitsland krapper is geworden. Overigens is de werkloosheid onder informatici in Oost-Duitsland meer dan twee keer zo hoog als in West-Duitsland. Het werkloosheidspercentage onder informatici in het westen van Duitsland ligt in 1996 op 6,8\% terwijl dit percentage voor het oosten op $18,3 \%$ ligt.

\section{De arbeidsmarkt voor Informatici naar opleiding}

Uit tabel 6.6 blijkt dat in $199534 \%$ van de werkenden in een informatica-beroep een hogere beroepsopleiding of academische opleiding heeft genoten. Meer dan de helft van de werkenden heeft een beroepsopleiding op lager of middelbaar niveau gevolgd.

Tabel 6.6

Werkenden in informatica-beroepen naar opleidingsniveau in Duitsland*, 1995

Opleidingsniveau

Zonder diploma beroepsopleiding

Lagere/middelbare beroepsopleiding

Hogere beroepsopleiding

Universitaire opleiding

Bron: Beschäftigtenstatistik 30.6.1995

* Deze data bevatten alleen degenen die sociale verzekeringen betalen. Hierin zijn niet de vrije beroepen en zelfstandigen meegenomen.

Tabel 6.7 geeft een overzicht van de opleidingsachtergronden van hoger opgeleiden werkzaam in een informatica-beroep. Van alle hoger opgeleiden die in 1993 werkzaam waren in een informatica-beroep had $38 \%$ een informatica-opleiding gevolgd. Bijna $60 \%$ van alle hoger opgeleiden werkzaam in het informatica-domein heeft een technische opleiding gevolgd.

In 1996 heeft 15\% van alle werkenden, dus ongeacht het opleidingsniveau, in het informatica-domein een informatica-opleidingsachtergrond. Maar dit aantal neemt evenals in Nederland steeds meer toe. Jaarlijks betreden er ongeveer 7.000 nieuwe schoolverlaters de arbeidsmarkt in het bezit van een diploma in de informatica. Hiervan hebben er ongeveer 4.000 een informatica-opleiding op hoger of universitair niveau gevolgd. Deze instroom is relatief laag vergeleken met de verwachte arbeidsmarktin-

9. De gegevens in deze tabel zijn gebaseerd op een andere beroepenclassificatie als de gegevens in tabel 6.3 (zie W. Dostal, 1996). 
stroom vanuit de hogere informatica-opleidingen in Nederland.

Tabel 6.7

Percentage werkenden met een hogere opleiding naar opleidingsrichting werkzaam in informaticaberoepen in Duitsland, 1993

\begin{tabular}{lr} 
Opleidingsrichting & $\%$ \\
\hline Hogere informatica & 38 \\
Andere hogere technische opleiding & 20 \\
Bestuurlijke/bedrijfskundige opleiding & 15 \\
Wiskunde & 9 \\
Econom(etr)ie/sociale wetenschappen & 6 \\
Pedagogische opleiding & 5 \\
Natuurkunde & 4 \\
Geesteswetenschappen & 3 \\
Rechten & 1
\end{tabular}

Bron: Mikrozensus (MZ)

Uit de gepresenteerde gegevens blijkt dat ook in Duitsland de arbeidsmarkt voor informatici steeds krapper wordt. Daar komt nog bij dat de informatica-beroepen steeds complexer worden waardoor in veel beroepen een informatica-opleiding toch steeds meer een vereiste wordt. Omscholing van nieuwkomers zonder een informaticaopleiding wordt daarom steeds moeilijker hetgeen het adequaat oplossen van knelpunten bemoeilijkt (Dostal, 1997).

\subsection{De arbeidsmarkt voor informatici in Groot-Brittannië}

In Groot-Brittannië ondervinden momenteel veel bedrijven knelpunten bij het aantrekken van informatici. Vooral vacatures voor programmeurs, analisten en voor computerondersteuning en netwerkbeheer zijn moeilijk te vervullen (IDS, 1997). Bovendien hebben de bedrijven ook problemen om personeel vast te houden. Men verwacht dat de bestaande tekorten de komende jaren nog nijpender zullen worden. De totale vraag naar automatiseringspersoneel zal naar verwachting over de periode 1996-1998 met $13 \%$ toenemen, dat is ruim $6 \%$ per jaar. Voor Nederland wordt de komende jaren een groei verwacht van iets meer dan $3 \%$ per jaar. Daarbij moet echter wel bedacht worden dat de prognoses voor Nederland betrekking hebben op een langere periode. Een deel van de extra vraag in Groot-Britannië is het resultaat van de verwachte problemen met computersystemen in het jaar 2000 . Ook de voorbereidingen voor de invoering van één Europese munt leiden tot extra vraag.

Tabel 6.8 geeft een overzicht van de verwachte uitbreidingsvraag voor verschillende beroepen binnen het informatica-domein. De grootste uitbreidingsvraag zal zich voordoen bij het ondersteunend personeel. Daarbij gaat het zowel om gebruikersondersteuning als technische ondersteuning. Hierbij valt te denken aan systeembeheer, het installeren van computers en dergelijke. Voor deze beroepen wordt een totale uitbreidingsvraag van bijna $15 \%$ verwacht, wat neerkomt op een gemiddelde jaarlijkse 
groei van rond de $7 \%$. De uitbreidingsvraag voor managers is daarentegen laag en de vraag naar operators neemt naar verwachting zelfs af.

\section{Tabel 6.8}

Procentuele uitbreidingsvraag in de informatica naar beroep in Groot-Brittanië, 1996-1998

Beroepsgroep

Managers

Systeemanalisten

Systeemontwikkelaars

Gebruiksondersteunend personeel

echnisch ondersteunend personeel

Netwerk personee

Operators

Totaal

Bron: NCC

De krapte op de arbeidsmarkt voor informatici in Groot-Brittannië wordt ook weerspiegeld in de hoge salarisgroei in de informatica-beroepen. Gemiddeld stegen de lonen over de periode 1996-1997 met 7,1\%. Voor programmeurs was de loonstijging in dat jaar zelfs bijna $10 \%$. Uit deze cijfers blijkt dat de problemen in Groot-Brittannië vergelijkbaar zijn met de problemen die in Nederland worden ondervonden.

Tabel 6.9

Procentuele salarisgroei in de informatica naar beroep in Groot-Brittannië, 1996-1997

\section{Beroep}

Technische ondersteunend/onderhoudspersoneel

Operators

Administratief personeel

Totaal

Bron: Computer Economics 


\section{Conclusies}

In dit rapport is de arbeidsmarkt voor informatici nader geanalyseerd om na te gaan of er sprake is van tekorten aan informatici en of deze tekorten structureel van aard of slechts een tijdelijk verschijnsel zijn. Eerst is een beeld geschetst van de ontwikkelingen in de eerste helft van de jaren ' 90 . Daarbij is onder andere ingegaan op ontwikkelingen in de werkgelegenheid in het informatica-domein, de opleidingsachtergrond van werkenden in het informatica-domein en de arbeidsmarktpositie van nieuwkomers in het informatica-domein. Vervolgens is ingegaan op de verwachte toekomstige ontwikkelingen op de arbeidsmarkt voor informatici. In dit hoofdstuk worden de belangrijkste resultaten samengevat.

De werkgelegenheid in de informatica-beroepen is met name in de jaren tachtig sterk toegenomen. In het begin van de jaren negentig bleef de werkgelegenheid vrij stabiel maar vanaf 1995 begint de werkgelegenheid in de informatica-beroepen weer te stijgen. Ook blijkt het werkgelegenheidsaandeel van informatica-beroepen in veel bedrijfssectoren de laatste jaren sterk toe te nemen. De werkgelegenheid in de informatica concentreert zich echter vooralsnog voornamelijk in de zakelijke dienstverlening. Andere sectoren waar het werkgelegenheidsaandeel van informatica-beroepen relatief groot is, zijn daarnaast het bank- en verzekeringswezen, de handel, de sector communicatie en de elektrotechnische industrie.

Het werkgelegenheidsaandeel van de werkenden met een informatica-opleidingsachtergrond is relatief laag. Wel neemt het aantal werkenden met een informatica-opleidingsachtergrond de laatste jaren sterk toe. Het aantal werkenden met een informaticaopleiding op universitair niveau is bijvoorbeeld de afgelopen vier jaar bijna verdubbeld. Toen de werkgelegenheid in de informatica begon op te komen waren er nog weinig reguliere informatica-opleidingen. Werkgevers namen daarom veel mensen in dienst die geen specifieke informatica-opleidingsachtergrond hadden. Via aanvullende cursussen en bedrijfstrainingen werden de vereiste informatica-vaardigheden dan alsnog bijgebracht. Met name om die reden werken er in de informatica-beroepen mensen met sterk uiteenlopende opleidingsachtergronden. $\mathrm{Nu}$ het aanbod van personen met een reguliere informatica-opleiding toeneemt proberen werkgevers zo veel mogelijk om mensen met een informatica-opleidingsachtergrond aan te stellen. Omdat kennis en vaardigheden van arbeidskrachten met een informatica-opleidingsachtergrond beter aansluiten bij de vereisten in de informatica-beroepen hoeven werkgevers voor deze groep minder scholingsinspanningen te leveren. Omdat tegelijkertijd ook de werkgelegenheid in het informatica-domein weer toeneemt blijft het aanbod van mensen met een informatica-opleidingsachtergrond echter ontoereikend.

De krappe arbeidsmarkt voor informatici wordt weerspiegeld door een gunstige arbeidsmarktpositie van de afgestudeerden van de informatica-opleidingen. Vanaf 1994 ligt de werkloosheid onder recent afgestudeerden uit de richting HBO informatica 
duidelijk onder het gemiddelde werkloosheidspercentage onder HBO'ers. Ook werkt men minder vaak onder $\mathrm{HBO}$-niveau en buiten de eigen vakrichting dan gemiddeld. Ten slotte wijzen ook de relatief hoge lonen van recent afgestudeerden op een krappe arbeidsmarkt.

Nog steeds blijken veel recent afgestudeerden die geen informatica-opleiding hebben afgerond in het informatica-beroependomein in te stromen. Het betreft met name mensen met een opleiding in de richting elektrotechniek op zowel middelbaar, hoger als wetenschappelijk niveau, maar ook mensen met een economische of administratieve opleidingsachtergrond. Deze nieuwkomers ondervinden vaker aansluitingsproblemen dan hun collega's die wel een informatica-opleiding hebben gevolgd. Zij volgen daarom vaker informatica-cursussen en hun lonen liggen gemiddeld wat lager. Overigens komen nieuwkomers zonder informatica-opleiding vaker in informaticaberoepen terecht waar vakspecifieke vaardigheden wat minder van belang zijn. Er moet dus onderscheid worden gemaakt tussen informatica-beroepen die makkelijker vervuld kunnen worden door mensen met een niet geheel aansluitende opleiding en de beroepen waarvoor een informatica-opleiding echt een vereiste is. Bij de laatstgenoemde functies zullen werkgevers meer moeite doen om mensen met een informaticaopleiding te vinden bijvoorbeeld door een hogere beloning of betere arbeidsvoorwaarden te bieden.

Ook de komende jaren zal het aanbod van nieuwkomers op de arbeidsmarkt met een informatica-opleiding op HBO- of WO-niveau sterk achterblijven bij de vraag. De tekorten op de arbeidsmarkt voor informatici blijken dus structureel van aard te zijn. De toegenomen vraag naar hoger opgeleiden met een informatica-opleidingsachtergrond is in belangrijke mate het gevolg van het 'opleidingseffect'. Informatica-beroepen worden steeds complexer. Daarom is een informatica-opleidingsachtergrond steeds belangrijker in deze beroepen. De meeste knelpunten als gevolg van een tekort aan hoger opgeleide informatici zullen naar verwachting worden ondervonden in de hogere en wetenschappelijke beroepen in het informatica-domein namelijk de Informatici, Elektrotechnici, Technisch systeemanalisten en Systeemanalisten. In de informaticaberoepen op middelbaar niveau, de Programmeurs, zullen werkgevers naar verwachting veel minder knelpunten ondervinden bij het rekruteren van personeel. De knelpunten in de informatica-beroepen zullen zich vooral voordoen in de sectoren zakelijke dienstverlening, bank- en verzekeringswezen, communicatie, handel en de metaal en elektrotechniek.

Een bijkomend probleem bij de verwachte knelpunten in de personeelsvoorziening in het informatica-domein is dat ook bij andere opleidingscategorieën die geworven worden voor informatica-beroepen, tekorten zullen optreden. Dat geldt bijvoorbeeld voor veel technische opleidingstypen zoals $H B O$ en WO elektrotechniek. Dit zal de substitutiemogelijkheden voor werkgevers beperken. Werkgevers zullen daarom ook de komende jaren grote inspanningen moeten leveren om geschikte kandidaten te 
vinden. Enerzijds kunnen zij informatici aantrekken door betere arbeidsvoorwaarden aan te bieden. Anderzijds zullen ze toch personen met een minder geschikte opleidingsachtergrond moeten blijven rekruteren en door middel van omscholing en bedrijfstrainingen deze nieuwkomers toch de vereiste vaardigheden bij brengen. Het gaat dan voornamelijk om personen met een vrij algemene opleidingsachtergrond (bijvoorbeeld met een opleiding HAVO of WWO voor programmeursfuncties) of mensen met een opleiding in de sociale wetenschappen. Ook het vergroten van de wervingsinspanningen in het buitenland zal waarschijnlijk niet erg veel soelaas bieden om de verwachte tekorten aan informatici te beperken omdat andere landen met soortgelijke problemen kampen, zoals blijkt uit de arbeidsmarktinformatie voor Duitsland en GrootBrittannië. Gezien het relatief lage percentage vrouwen dat werkzaam is in het informatica-domein, zeker in vergelijking met Duitsland, zal het stimuleren van de instroom van vrouwen in informatica-beroepen meer perspectief kunnen bieden. 


\section{Literatuur}

Baber, R.L. (1992), W. Dostal, J-P. Rotermind, E. Schwarz, B. Wix, Zur Berufssituation der Informatiker 1991, Ergebnisse der Mitgliederbefragung der GI 1991/92, Informatik-Spektrum, 15, pp 335-351.

Berenschot Informatica (1997), Salarisenquête automatiseringspersoneel 1997, Berenschot.

Borghans, L. (1995), A. de Grip, R. Dekker, A. Matheeuwsen, W. Smits, E. Willems, Methodiek van het Informatiesysteem Ondenwijs-Arbeidsmarkt 1995, ROA-W-1995/3, Maastricht.

Borghans, L. (1997), A. de Grip, W. Smits, H. Zuurbier, Het beroependomein van opleidingen, ROA-R-1997/2, Maastricht.

CBS(1993), Standaard Beroepenclassificatie 1992, Sdu/Uitgeverij, Den Haag

CBS(1997a), Automatisering in Nederland, Centraal Bureau voor de Statistiek, Voorburg/Heerlen. CBS(1997b),Automatiseringsstatistieken, particuliere sector 1995-1997, Centraal Bureau voor de Statistiek, Voorburg/Heerlen.

Dostal, W (1995), Berufsbilder in der Informatik, Informatik-Spektrum, 18, pp 152-162.

Dostal, W. (1996), Arbeitsmarkt für Computerberufe leicht erholt;Materialien aus der Arbeitsmarktund Berufsforschung, Nr.2.

Dostal, W (1997), Informatik-Qualifikationen im Arbeitsmarkt, Informatik-Spektrum, 20, pp 73-78. Income Data Services (1997), Computer Staff Pay, IDS Study 629, july 1997.

Kivi(1995), Ingenieur en Salaris, Een onderzoek naar primaire en secundaire arbeidsvoorwaarden onder TU-ingenieurs, Kivl adviesreeks nr. 5

LDC (1996), Beroepen van $A$ tot $Z$, informatie over beroepen vanaf MBO-niveau, Stichting Landelijk Dienstverlenend Centrum voor Studie- en Beroepskeuzevoorlichting, Leeuwarden.

Muysken, J. (ed.) (1994), Measurement and Analysis of Job Vacancies: an International Comparison, Avebury, Aldershot.

Nibbering H.C.(1995), M. Nitzsche, Vacature-barometer voor ingenieurs, Ontwikkelingen in het vacature-aanbod en korte termijn voorspellingen, KIvl adviesreeks $\mathrm{nr} .9$.

Nibbering H.C.(1997), M. Nitzsche, Vacature-barometer voor ingenieurs, Ontwikkelingen in het vacature-aanbod in 1995, 1996 en het eerste kwartaal van 1997, Kivi adviesreeks $\mathrm{nr} .9$.

ROA (1997a), De arbeidsmarkt naar opleiding en beroep tot 2002, ROA-R-1997/7, Maastricht. ROA (1997b), Statistische Bijlage, De arbeidsmarkt naar opleiding en beroep tot 2002, ROA-R1997/7B, Maastricht. 


\section{Bijlage 1 Informatica-beroependomein}

Tabel 1

Beroepen waarin werkenden 'informatica ontwikkelen en adviseren' (werksoort 20) of 'informatica beheren, verwerken' (werksoort 21)

$\begin{array}{lll}\text { SBC'92 5-digit code } & \begin{array}{l}\text { Informatica ontwikkelen, } \\ \text { adviseren }\end{array} & \begin{array}{l}\text { Informatica beheren, } \\ \text { verwerken }\end{array}\end{array}$

Elektronicamonteurs

46601

46602

46603

46604

46605

Programmeurs

51401

51402

Technisch systeemanalisten

66601

66602

$x$

66603

66604

66605

66606

66607

66608

66609

66010

66611

$\mathrm{x}$

Systeemanalisten

71401

71402

71403

71404

71405

71406

71407

71408 


$\begin{array}{lll}\text { SBC'92 5-digit code } & \begin{array}{l}\text { Informatica ontwikkelen, } \\ \text { adviseren }\end{array} & \begin{array}{l}\text { Informatica beheren, } \\ \text { verwerken }\end{array}\end{array}$

\section{Elektrotechnici}

86601

86602

86603

86604

86605

86606

86701

86702

86703

\section{Informatici}

$\begin{array}{ll}91401 & \mathrm{x} \\ 91402 & \mathrm{x}\end{array}$

Bron : CBS

Toelichting:

De tabel geeft per beroepsgroep voor elk onderliggend beroep aan of de werksoorten 'informatica ontwikkelingen, adviseren' en 'informatica beheren, verwerken' van toepassing zijn. De beroepgroep Electronicamonteurs is uiteindelijk niet tot het informatica-domein gerekend omdat het aantal werkenden dat zich bezighoudt met één van beide werksoorten te gering is 
Tabel 2

Koppeling tussen de onderscheiden beroepsgroepen en LDC beroepen

\section{Programmeurs}

beheerder programmabibliotheek

computeroperator

help-desk medewerker

\section{Technisch systeemanalisten/Elecktrotechnici}

telematica-adviseur

telematicatechnicus

technisch-wetenschappelijk analist

constructeur meet- en regeltechniek

instrumentatietechnicus

besturingstechnicus

\section{Systeemanalisten/Informatici}

adviseur interne controle en beveiliging

bedrijfskundig informaticus

informatieanalist

produktieanalist

programmeur

systeemontwikkelaar

telecommunicatiemanager

systeembeheerder

netwerkbeheerder

\section{Bron: LDC/ROA}

\section{Toelichting:}

De tabel geeft een koppeling tussen beroepsgroepen op basis van de SBC'92 en de beroepen die door het LDC worden onderscheiden in de reeks Beroepen van $A$ tot $Z$ (LDC 1996). In deze publicatie wordt per beroep een uitvoerige beschrijving gegeven van de werkzaamheden. Er wordt echter door het LDC geen onderscheid gemaakt tussen beroepen op een hoger niveau en beroepen op wetenschappelijk niveau. Verder geldt dat niet alle informatie-beroepen die door het CBS worden onderscheiden ook door het LDC zijn beschreven. 


\section{Bijlage 2 Indicator voor knelpunten in de personeels- voorziening per beroep}

Het ROA opleidingenmodel genereert prognoses voor de verwachte vraag naar verschillende opleidingstypen per beroepsgroep. Op basis van deze vraag en het aanbod van verschillende opleidingen kan een indicator worden geconstrueerd voor de verwachte knelpunten die zullen worden ondervonden in de personeelsvoorziening per beroepsgroep in 2002.

Het aanbod van een opleidingstype $i$ in $2002\left(y_{i}^{02}\right)$ is gelijk aan het aanbod in 1997 plus de arbeidsmarktinstroom van schoolverlaters in de periode 1997-2002 minus de vervangingsvraag over dezelfde periode, dus :

(a.1) $y_{i}^{02}=x_{i}^{97}+w / h_{i}^{97}+$ instr $-v v_{i}$

Waar :

$\boldsymbol{x}_{\boldsymbol{i}}^{\mathbf{9 7}}$ het totaal aantal werkenden met opleiding $i$ in 1997

$w^{\prime} h_{i}^{97}$ het aantal kortdurige werklozen met opleidingstype $i$ in 1997

instr $r_{i}$ de arbeidsmarktinstroom van schoolverlaters met opleidingstype $i$ voor de periode 1997-2002

$v v_{i} \quad$ de vervangingsvraag voor opleidingstype $i$ in over de periode 1997-2002

De kans om een werknemer aan te trekken met opleidingstype $i$ wordt gegeven door:

(a.2a) $p_{i}=\frac{y_{i}^{02}}{x_{i}^{02}} \quad$ als $y_{i}^{02} \leq x_{i}^{02}$

(a.2b) $p_{i}=1 \quad$ als $y_{i}^{02}>x_{i}^{02}$

$\boldsymbol{x}_{i}{ }^{02}$ is de verwachte vraag naar opleiding $i$ in 2002 . We veronderstellen dus dat de kans om iemand met opleidingstype $i$ aan te trekken gelijk is voor alle beroepsgroepen. Dat betekent dat tekorten proportioneel over beroepen verdeeld zullen zijn.

Een indicator voor knelpunten als gevolg aanbodtekorten bij opleidingen waar vraag naar is vanuit beroep $j$ wordt dan gegeven door:

(a.3) ITKB $=\frac{\sum_{i} p_{i} x_{i j}{ }^{02}}{\sum_{i} x_{i j}{ }^{02}}, 0 \leq I T K B \leq 1$

De noemer geeft de totale vraag vanuit beroepsgroep $j$ en de teller de verwachte vervulling van deze vraag. De ITKB geeft dus de mate waarin de vraag vanuit beroepsgroep $j$ in de gewenste samenstelling vervuld zal kunnen worden. Naarmate de 
waarde van ITKB lager is, zijn er meer knelpunten te verwachten. Als ITKB=1 dan worden er geen knelpunten verwacht bij het vervullen van de vraag vanuit beroepsgroep $j$. Een ITKB van 0 zou betekenen dat de vraag vanuit beroep $j$ in het geheel niet vervuld zou kunnen worden. De ITKB is een relatieve maatstaf voor knelpunten. De waarde van de ITKB is getypeerd op basis van de kwantiele methode. De grenzen voor deze typering zijn zo bepaald dat in elke klasse ongeveer $20 \%$ van de beroepsgroepen valt.

Dit geeft de volgende grenzen:

$\begin{array}{lll} & I T K B \leq 0,88 & \text { zeer groot } \\ 0,88< & I T K B \leq 0,91 & \text { groot } \\ 0,91< & I T K B \leq 0,93 & \text { enige } \\ 0,93< & I T K B \leq 0,94 & \text { vrijwel geen } \\ 0,94< & I T K B \leq 1 & \text { geen }\end{array}$

De indicator geeft aan in welke mate het mogelijk is om de gewenste personeelsamenstelling te bereiken maar houdt geen rekening met de mogelijkheid om tekorten bij een opleiding aan te vullen door mensen met een andere (aanverwante) opleiding te rekruteren. In de ene beroepsgroep zal substitutie tussen opleidingen makkelijker zijn dan in de andere beroepsgroep. Daarbij is ook het aanbod van andere opleidingen van belang. Het is namelijk mogelijk dat er in principe wel veel substitutiemogelijkheden tussen opleidingen zijn maar dat het aanbod bij deze andere opleidingen ook tekort schiet.

Daarnaast wordt ook geen rekening gehouden met het potentiële aanbod van niet werkenden. Alleen kortdurige werklozen worden tot het aanbod gerekend. Deze veronderstelling is te rechtvaardigen door er vanuit te gaan dat werkgevers pas herintreders gaan rekruteren op het moment dat ze daadwerkelijk knelpunten ondervinden. Bij personen die zich lang buiten het arbeidsproces hebben bevonden zal vaak sprake zijn van scholingsveroudering waardoor werkgevers extra inspanning moeten leveren, bijvoorbeeld door middel van bijscholing, om deze mensen in te zetten.

In de praktijk zal ook de kans om iemand met een bepaald opleidingstype te rekruteren verschillen tussen beroepen. In beroepen waar weinig substitutiemogelijkheden zijn zullen werkgevers eerder bereid zijn om meer loon te bieden om op die manier de kans te vergroten iemand met de gewenste opleidingsachtergrond aan te trekken. Ook hier geldt het argument dat de lonen worden verhoogd omdat er sprake is van knelpunten. Als hier van te voren al rekening mee zou worden gehouden zouden de knelpunten worden onderschat. 
